\title{
Badania georadarowe kemów jako przykład możliwości zastosowania metod geofizycznych do badania form zbudowanych z drobnoziarnistych osadów klastycznych GPR surveys of kame hills as an example of geophysical methods being applied to the study of forms built of fine- grained clastic sediments
}

\author{
Piotr Lamparski \\ Instytut Geografii i Przestrzennego Zagospodarowania im. S. Leszczyckiego PAN \\ ul. Kopernika 19, 87-100 Toruń \\ piotr.lamparski@twarda.pan.pl
}

\begin{abstract}
Zarys treści. W artykule wskazano na możliwości poszerzenia spektrum informacji o wykształceniu się strukturalno-teksturalnym osadów glacilimnicznych poprzez zastosowanie metody georadarowej. Omówiono istotę rozpoznania osadów za pomocą aparatury georadarowej, a także parametry geofizyczne drobnoziarnistych osadów klastycznych. Zaprezentowano rezultaty badań georadarowych pagórków kemowych na czterech reprezentatywnych stanowiskach zlokalizowanych na Wysoczyźnie Chełmińskiej. Ukazano makroskalowy układ facji georadarowych będący obrazem struktur sedymentacyjnych.

Dwa pierwsze stanowiska to leżące blisko siebie pagórki kemowe okolic Owieczkowa o odmiennej strukturze facji georadarowych, co wskazuje na różnice w ich morfogenezie. Następne stanowisko to pagórek kemowy w Zapluskowęsach, charakteryzujący się regularnym kształtem i zbudowany z jednorodnego materiału. Ostatnim jest pagórek kemowy w Piątkowie, w którym znajduje się znacznych rozmiarów odsłonięcie. Równolegle do ściany odsłonięcia, w jej bezpośredniej bliskości, został przeprowadzony przekrój georadarowy. W ścianie odsłonięcia przeprowadzono badania właściwości elektrycznych osadów, które posłużyły do kalibracji rezultatów profilowań georadarowych.

Na podstawie interpretacji wyników badań georadarowych wskazano na specyfikę morfogenezy poszczególnych pagórków kemowych, a także na zaobserwowane za pomocą georadaru struktury postsedymentacyjne. Przeprowadzono ocenę przydatności metody GPR do badań form glacilimnicznych zbudowanych z osadów drobnoklastycznych. W artykule wskazano na duży potencjał metody GPR w ocenie budowy makroskalowej pagórków kemowych i pośrednio genezy poszczególnych form, szczególnie w kontekście ustalenia ich pozycji w strefie marginalnej lądolodu.
\end{abstract}

Słowa kluczowe: kemy, georadar, badania geofizyczne, osady klastyczne, Niż Polski.

Keywords: kames, Ground Penetrating Radar, geophysical research, clastic sediments, Polish Lowland.

\section{Wstęp}

Większość informacji o osadach uzyskiwanych metodami bezpośrednimi ma charakter punktowy lub w przypadku istnienia odsłonięć, lokalnie liniowy. Rozszerzenie wyników badań na większe obszary jest zwykle obarczone dużym błędem niepewności. Tworzenie zaś z wielu przybliżonych badań punktowych i liniowych całościowego obrazu osadu 
często jest trudne lub niemożliwe. Lukę tę wypełniają badania pośrednie (w tym geofizyczne) począwszy od badań elektrooporowych, tomografii elektrooporowej, płytkich badań sejsmicznych, badań georadarowych, aż po multispektralne obrazowania satelitarne (Van Dam, 2012). Wśród metod pośrednich badania przypowierzchniowej warstwy Ziemi dobrym kompromisem pomiędzy dokładnością, dużą rozdzielczością, szybkością pomiaru i dużą skalą badanych obiektów jest metoda georadarowa zwana też metodą geofizycznego profilowania radarowego (ang. Ground Penetrating Radar). Metoda ta daje możliwości rejestracji dawnych powierzchni, ścięć erozyjnych, płaszczyzn uskoków i innych struktur w osadzie, określenia ich charakteru, wysokości i rozciągłości (Busby i Merritt, 1999; Russel i inni, 2001; Kostic i inni, 2005; Czuryłowicz i inni, 2014; Lejzerowicz i inni, 2014). Pozwala również stworzyć model pseudo trójwymiarowy osadu (Beres i inni, 1995; Beres i inni, 1999; Lamparski, 2004; Kostic i inni, 2005).

Do pionierskich prac w zakresie wykorzystania metody GPR w Polsce należą sondowania jeziora Dąbie (Razowski, 1985; Piotrowski, 1989), sondowania Krzemionek Opatowskich (Borkowski, 1990), a także prace autora artykułu (Lamparski, 1992). W latach 90. XX w. obserwuje się stopniowy wzrost zainteresowania metodami płytkiego rozpoznania geofizycznego $\mathrm{w}$ badaniach geologicznych w Polsce. Zaś ostatnie lata przynoszą wiele interesujących opracowań i można stwierdzić, że metoda GPR wyszła już z fazy eksperymentu i stała się pełnoprawną metodą pomocniczą w pracy geologa i geomorfologa (Olszak i Karczewski, 2008; Słowik, 2011a, 2011b; Lejzerowicz i inni, 2014; Słowik, 2014a, 2014b; Lejzerowicz i Kowalczyk, 2016; Lejzerowicz, 2018; Lejzerowicz i Kowalczyk, 2018).

Formy wodnolodowcowe powstałe w czasie zlodowaceń plejstoceńskich na obszarze Niżu Polskiego są szczególnie predysponowane do badań metodą profilowania radarowego i zajmują wśród form zbudowanych z osadów klastycznych tego rejonu szczególną pozycję. Zwykle budują je piaski, mułki oraz żwiry. Stosunkowo liczne są opracowania koncentrujące się na specyficznych środowiskach depozycyjnych. Większość z nich dotyczy zastosowania georadaru do badania nieskonsolidowanych osadów klastycznych - żwirów i piasków (Ulriksen, 1982; Moorman i inni, 1991; Beres i inni, 1995; Smith i Jol, 1995; Jol i inni, 1996; Beres i inni, 1999; Lamparski, 2001; Lejzerowicz i inni, 2012; Żuk i Sambrook Smith, 2015; Lejzerowicz i inni, 2018). Struktura osadów form wodnolodowcowych, w których najczęściej wyróżnić można sekwencje serii piaszczystych i mułkowych poprzecinanych licznymi uskokami, jest również ważnym czynnikiem sprzyjającym przydatności metody GPR. Zarówno granice osadów, jak i przecinające je uskoki stanowią granice (strefy) nieciągłości właściwości elektrycznych osadu i z punktu widzenia metody profilowania radarowego generują doskonałej jakości echa podczas rejestracji odbitego od nich sygnału radarowego. Ponadto istnienie kemów, ozów, ale także wydm w postaci izolowanych form, wyniesionych ponad poziom gliny morenowej powoduje, że osady je budujące są zwykle suche, a pierwszy poziom wodonośny występuje zwykle niewiele wyżej ponad poziom stropu gliny. Duża miąższość suchych osadów klastycznych sprzyja dobrej propagacji fal elektromagnetycznych i w konsekwencji pozwala na stosunkowo głęboką penetrację osadu przy pomocy georadaru (Davis i Annan, 1989; Lamparski, 2004).

Wzajemna konfiguracja linii i płaszczyzn w utworzonym w czasie badania georadarowego modelu osadu tworzy charakterystyczne zespoły struktur. Przez analogię do badań sedymentologicznych na obrazach georadarowych wydziela się różne pod względem kształtu, nachylenia, relacji oraz ciągłości, układy linii, powierzchni i trójwymiarowych pakietów struktur (Neal, 2004). Tak wydzielone kryteria pozwalają tworzyć następnie klasy struktur 
zwane w literaturze facjami radarowymi - ang. radar facies (Huggenberger i inni, 1994; Van Overmeeren, 1998; Beres i inni, 1999; Overgaard i Jakobsen, 2001; Jakobsen i Overgaard, 2002; Neal, 2004; Lejzerowicz i inni, 2014; Żuk i Sambrook Smith, 2015; Lejzerowicz i inni, 2018). Prowadzone są również badania mające na celu weryfikację tworzonej w ten sposób stratygrafii radarowej. Wielu badaczy stwierdza dużą zgodność facji radarowych ze strukturami sedymentacyjnymi w osadzie (Van Overmeeren, 1998; Jakobsen i Overgaard, 2002; Neal, 2004; Sadura i inni, 2006; Olszak i Karczewski, 2008; Słowik, 2012).

Pojęcie facji radarowych obejmuje zmiany własności elektrycznych i magnetycznych osadu wynikające przede wszystkim ze zmian wilgotności, które z kolei są często podkreślone przez jego cechy strukturalno-teksturalne (Neal, 2004). Wilgotność osadu związana jest również z innymi jego właściwościami, jak choćby z zawartością materii organicznej. Obecność wody w poszczególnych warstwach geologicznych jest najistotniejszym czynnikiem warunkującym występowanie na falogramach georadarowych wyraźnych linii (Van Overmeeren, 1998; Van Dam i Schlager, 2000). Wiąże się to z dużym kontrastem pomiędzy wartością stałej dielektrycznej dla wody (81) i osadu suchego (4-8). Obecność wody może wynikać także z ułożenia klastów w osadzie (Neal, 2004). Należy jednak zauważyć, że istnieje wiele środowisk geologicznych, w których pojęcia facji radarowej i facji litostratygraficznej osadu opisują różne właściwości osadu i dotyczą zupełnie różnych struktur, gdzie interpretacja anomalii georadarowych bywa niepewna. Jednym z takich przypadków są środowiska geologiczne, w których duże znaczenie mają wytrącenia związków żelaza, występujące szczególnie w strefie saturacji (Van Dam i inni, 2002). Osady klastyczne zawierające związki żelaza są na Niżu Polskim powszechne i obejmują wiele znanych typów genetycznych osadów. Wytrącenia tlenków i wodorotlenków żelaza towarzyszą strefom ułatwionej infiltracji wody w osadzie (płaszczyzny uskoków, dawne powierzchnie rozmycia), ale również stanowią ślad działania dawnych procesów. Częstym miejscem wzbogacenia osadów w związki żelaza jest warstwa peryglacjalnego kontaktu krioiluwialnego będąca reliktem dolnej granicy warstwy czynnej wieloletniej zmarzliny (Kowalkowski, 2004; Van Loon i inni, 2012). W tym przypadku istnienie wytrąceń związków żelaza może stanowić utrudnienie w interpretacji obrazów GPR, gdyż wytrącenia te mogą występować niezgodnie z granicami litostratygraficznymi. Na odmienną sytuację wskazują K. Czuryłowicz i inni (2014) oraz A. Lejzerowicz i inni (2014), którzy istnienie warstw scementowanych tlenkami i wodorotlenkami żelaza w piaskach kwarcowo-glaukonitowych, zgodnych z ułożeniem jednostek litostratygraficznych, traktują jako granice facjalne silnie reagujące z falami elektromagnetycznymi i generujące łatwo rozpoznawalne anomalie na profilach georadarowych.

Celem tego artykułu jest pokazanie możliwości poszerzenia spektrum informacji o sposobie wykształcenia się struktury i tekstury osadów w skali całej badanej formy poprzez zastosowanie metody georadarowej do badania wybranych pagórków kemowych położonych na Wysoczyźnie Chełmińskiej (ryc. 1). Poza niewątpliwymi aspektami poznawczymi metoda GPR niesie ze sobą pierwiastek niepewności, który wynika ze specyfiki zarówno metody, jak i obiektu badań. Niektóre z ograniczeń zostaną wskazane w trakcie omawiania wyników badań.

Do szczegółowych analiz wytypowano cztery pagórki o zróżnicowanej budowie geologicznej, co pozwala na przeprowadzenie analizy porównawczej uzyskanych wyników. Większość z nich reprezentuje, według klasyfikacji Niewiarowskiego (1961), kemy glacilimniczne. Wyjątek stanowi kem w Piątkowie, który w dużej części przykryty jest niewiel- 
kiej miąższości gliną spływową. Dwa stanowiska to leżące blisko siebie pagórki kemowe okolic Owieczkowa, które mimo bliskości mają odmienną strukturę anomalii georadarowych, co wskazuje na różnice w ich morfogenezie. Na przykładzie stanowisk w Owieczkowie zostaną również pokazane możliwości rozpoznania struktur postsedymentacyjnych na przekrojach georadarowych.

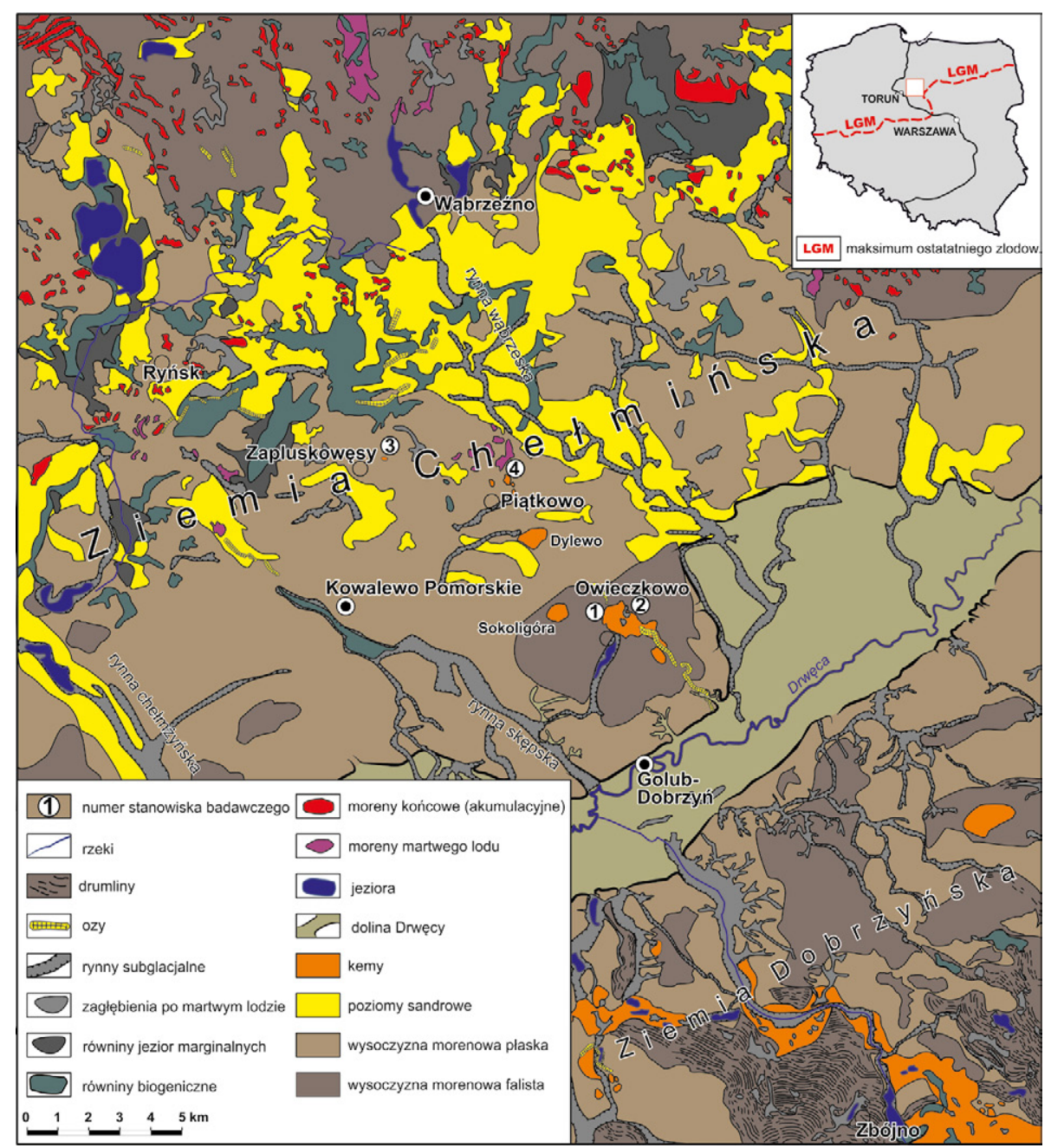

Ryc. 1. Szkic geomorfologiczny obszaru badań

Stanowiska badawcze: 1 - zachodni kem owieczkowski, 2 - wschodni kem owieczkowski, 3 - kem w Zapluskowęsach, 4 - kem w Piątkowie

Geomorphological sketch of the study area

Opracowanie własne na podstawie Szczegółowej Mapy Geologicznej Polski w skali 1: 50 000, ark. 283 Wąbrzeźno (Drozd i Trzepla, 2005a), ark. 284 Książki (Drozd i Trzepla, 2005b), ark. 322 Kowalewo Pomorskie (Błaszkiewicz i Kordowski, niepublikowane) i ark. 323 Golub-Dobrzyń (Wysota, 2007).

Author's own elaboration based on the Detailed Geological Map of Poland on a scale of 1:50 000, Sheets 283 Wabrzeźno (Drozd and Trzepla, 2005a), 284 Ksiqżki (Drozd and Trzepla, 2005b), 322 Kowalewo Pomorskie (Błaszkiewicz and Kordowski, unpublished) and 323 Golub-Dobrzyń (Wysota, 2007). 
Następnie pokazane i omówione zostaną rezultaty badań georadarowych pagórka kemowego w Zapluskowęsach. Zaprezentowany będzie układ facji georadarowych, będących obrazem struktur sedymentacyjnych osadów w przekrojach podłużnych i poprzecznych formy. Przekroje geofizyczne przecinają całą formę i doskonale pokazują obraz makrostruktur osadów. Ostatnim stanowiskiem jest pagórek kemowy w Piątkowie, w którym znajduje się znacznych rozmiarów odsłonięcie. Równolegle do ściany odsłonięcia, w jej bezpośredniej bliskości, został przeprowadzony przekrój georadarowy. Otrzymano $w$ ten sposób wiarygodny obraz kalibracyjny metody georadarowej. Stanowisko to jest istotne ze względu na możliwość bezpośredniego porównania struktur sedymentacyjnych osadów z układem anomalii geofizycznych tworzących system anomalii georadarowych. W ścianie odsłonięcia przeprowadzono badania właściwości elektrycznych osadów, które posłużyły do kalibracji rezultatów sondowań georadarowych, uzyskanych na tym oraz na innych omawianych stanowiskach.

\section{Metoda badań}

Po analizie literatury tematu, materiałów kartograficznych i rekonesansowych wyjazdach terenowych, do badań wytypowano pagórki kemowe położone w kilku miejscach Wysoczyzny Chełmińskiej. Przeprowadzono terenowe pomiary geodezyjne badanych form oraz digitalizację map topograficznych w celu stworzenia cyfrowych modeli badanych kemów. Przeprowadzono również przegląd istniejących zdjęć lotniczych, a także analizę odsłonięć w badanych formach. Wykonano wiercenia ręczne w osadach przypowierzchniowych oraz wiercenia sondą mechaniczną do stropu gliny w kulminacjach trzech pagórków (Owieczkowo i Zapluskowęsy). Zebrano dokumentację dotyczącą parametrów geoelektrycznych osadów przy pomocy urządzeń do rejestracji przewodności właściwej Ejkelkamp Earth Resistivity Meter i stałej dielektrycznej HH Meter Delta-T Device.

Podstawową metodą badawczą było geofizyczne profilowanie radarowe (ang.: Ground Penetrating Radar - GPR). Zastosowano aparaturę GSSI IM SIR SYSTEM-2000. Zestaw składa się z jednostki centralnej oraz anten o częstotliwościach pracy $35 \mathrm{MHz}, 100 \mathrm{MHz}, 300 \mathrm{MHz}$ i $400 \mathrm{MHz}$. Anteny te pozwalają na penetrację osadu klastycznego w sprzyjających warunkach nawet do 30-40 metrów (anteny o niskich częstotliwościach - np. $35 \mathrm{MHz}$ ), a także uzyskanie kilkucentymetrowej rozdzielczości uzyskanego obrazu (anteny o wysokich częstotliwościach - np. 300 i 400 MHz) (Morey, 1974; Smith i Jol, 1995; Lamparski, 2004). Niestety zasięg badania jest odwrotnie proporcjonalny do zdolności rozdzielczej. Zatem antena o częstotliwości $35 \mathrm{MHz}$ pozwala uzyskać rozdzielczość pionową w piasku suchym około $1 \mathrm{~m}$, zaś antena $400 \mathrm{MHz}$, około $8 \mathrm{~cm}$. Radar SIR SYSTEM-2000 może być stosowany w trudnych warunkach terenowych poprzez zawieszenie całej aparatury na operatorze, a także w warunkach większej dostępności terenu na specjalnym wózku (fot. 1 A, B).

Metoda geofizycznego profilowania radarowego (ang. Ground Penetrating Radar) bazuje na zjawiskach odbicia i pochłaniania fal elektromagnetycznych w różnych środowiskach geologicznych (Morey, 1974; Annan i Davis, 1976, 1977). Moc sygnału odbitego od granic „facjalnych” oraz czas jego powrotu są rejestrowane przez aparaturę nadawczo-odbiorczą. Badanie odbywa się w czasie rzeczywistym i prowadzone jest z dużą gęstością próbkowania (impulsy co kilka cm bieżących) wzdłuż wybranych linii przekrojów. W efekcie otrzymuje się pseudo-przekroje osadu, w których skala pozioma (przy założeniu popraw- 


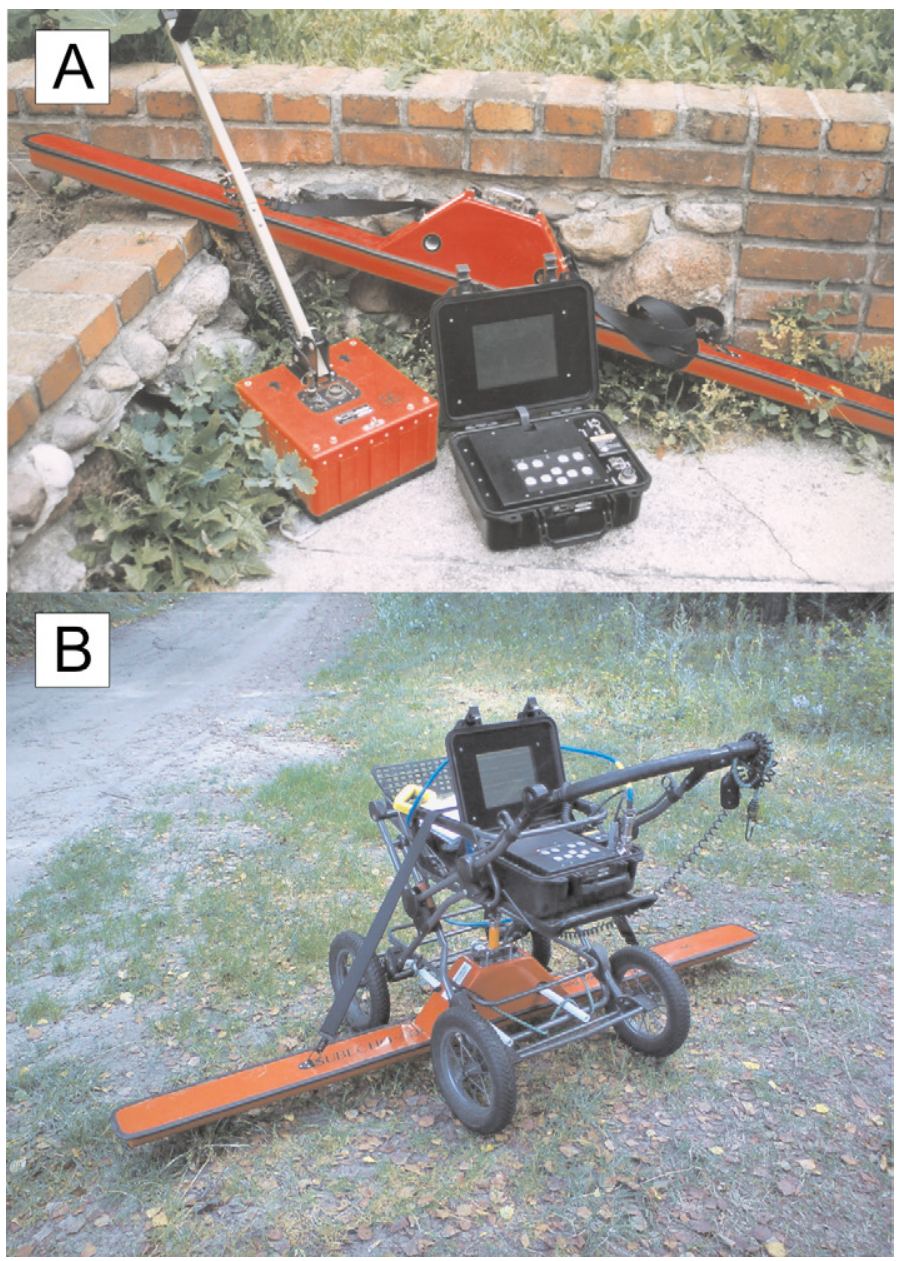

Fot. 1. Aparatura georadarowa SIR SYSTEM-2000 z antenami 400 i $35 \mathrm{MHz}(\mathrm{A})$, z anteną $35 \mathrm{MHz}$ na specjalnie zaadaptowanym wózku (B) (fot. Piotr Lamparski)

Ground Penetrating Radar SIR SYSTEM-2000 with $400 \mathrm{MHz}$ and $35 \mathrm{MHz}$ antennae (A), GPR device with $35 \mathrm{MHz}$ antenna on custom-built 4-wheel cart (B).

nej i częstej kalibracji koła sterującego pracą radaru oraz weryfikacji skali bezpośrednim pomiarem) jest rzeczywistą skalą odległości, a skala pionowa pokazuje czas powrotu impulsów fal elektromagnetycznych do anteny. Tak otrzymany falogram jest modelem czasowym (oś pionowa jest osią czasu) przekroju geologicznego osadu, w którym konfiguracja zaburzeń zależna jest głównie od wartości stałej dielektrycznej w poszczególnych pakietach osadów (Ulriksen, 1982; Davis i Annan, 1989; Lamparski, 2004).

Do kalibracji metody georadarowej wykorzystano aparaturę do pomiaru oporności gruntu Earth Resistivity Meter Ejkelkamp oraz aparaturę HH2 Moisture Meter Delta-T Devices z sondą ThetaProbe do pomiaru wilgotności osadu metodą FDR - ang. Frequency Domain Reflectometry. Metoda FDR jest szybkim i stosunkowo tanim sposobem określenia przybliżonej rzeczywistej wartości stałej dielektrycznej osadu, a w konsekwencji określenia 
skali pionowej przekrojów georadarowych (Beiping, 1996; Minet i inni, 2010). Empiryczna zależność pomiędzy objętościową wilgotnością względną osadu klastycznego a stałą dielektryczną, zwana równaniem Topp'a (ang. Topp's Equation), znana jest od początku lat osiemdziesiątych XX wieku (Topp i inni, 1980). Jego zmodyfikowaną wersją, wiążącą surowy odczyt danych napięcia elektrycznego z miernika FDR (HH2 Moisture Meter Delta-T Devices) ze stałą dielektryczną jest poniższe równanie trzeciego stopnia, które w zakresie wilgotności objętościowej osadu od 0 do 55\% ( $V=0 \div 1$ Volta) sprawdza się ze współczynnikiem korelacji $R^{2}=0,998$ (Theta Probe User Manual, 1998; Raed i inni, 2014):

$$
\sqrt{\varepsilon}=1,07+6,4 V-6,4 V^{2}+4,7 V^{3} \quad\left(R^{2}=0,998\right)
$$

gdzie: $\varepsilon$ - stała dielektryczna, $V$ - napięcie elektryczne $(V), R$ - współczynnik korelacji

Obróbka danych georadarowych dokonana została za pomocą specjalistycznego oprogramowania interpretacyjnego RADAN (GSSI ${ }^{\mathrm{TM}}$ RAdar DAta Analyser). Wykonano standardowe procedury filtracyjne obejmujące m.in. rozplatanie sygnałów (ang. deconvolution), filtrację dolno- i górnoprzepustową, migrację sygnałów hiperbolicznych, korektę topograficzną i wzmacnianie sygnału automatyczne i ręczne. Cyfrowe modele terenu wykonano za pomocą programu Surfer, zaś końcowa edycja i interpretacja graficzna falogramów georadarowych wykonana została za pomocą pakietu CorelDraw.

Zaprezentowane wyniki badań stanowią tylko część wykonanych w obrębie stanowisk badawczych profili georadarowych. Ponadto, ze względu na ograniczenia techniczne, znacznych rozmiarów profile georadarowe można w tym artykule zaprezentować jedynie w wersji mocno pomniejszonej. Odbija się to niestety na ich czytelności.

\section{Wyniki badań}

Obszar kemowy rozciągający się na obszarze Ziemi Dobrzyńskiej i Ziemi Chełmińskiej, od pagórków owieczkowskich na południu, poprzez kemy w Sokoligórze, Dylewie i Piątkowie, aż po izolowaną formę w Zapluskowęsach na północy, był opisywany przez Niewiarowskiego (1959) i Wysotę (2007) (ryc. 1).

Cały obszar badawczy położony jest na Ziemi Chełmińskiej, na północ od Golubia-Dobrzynia, w pasie wysoczyzny morenowej płaskiej i falistej, rozciągającej się na południe od moren południowo-wąbrzeskich, aż po dolinę Drwęcy (ryc. 1). Wysoczyzna Chełmińska jest powiązana z fazą kujawsko-dobrzyńską lądolodu górnovistuliańskiego (Niewiarowski, 1959). Jest to jedna z lokalnych faz recesyjnych fazy poznańskiej ostatniego zlodowacenia. Obszar ten poprzecinany jest rynnami subglacjalnymi, biegnącymi przeważnie w kierunku NW-SE. Największe z nich, chełmżyńska i wąbrzeska (ryc. 1) ograniczają obszar badawczy odpowiednio od zachodu i wschodu. Podobny kierunek przebiegu mają pomniejsze rynny (np. rejonu Kowalewa Pomorskiego) oraz ozy i ciągi pagórków kemowych od Owieczkowa po Zapluskowęsy, znaczące trasy odpływu wód roztopowych z lądolodu (Niewiarowski, 1959). Obszar ten, rozciągający się na południe od moren okolic Wąbrzeźna, przez W. Niewiarowskiego (1959) rozpoznany został jako obszar deglacjacji arealnej ze względu na liczne występowanie form szczelinowych, moren martwego lodu i zagłębień wytopiskowych. W. Niewiarowski ponadto zwraca uwagę na istnienie w okolicach Kowalewa Pomorskiego i Owieczkowa wyniesień podłoża podczwartorzędowego, na których miąższość utworów 
czwartorzędowych wynosi jedynie 10-30 m. Istnienie tych wyniesień, w jego opinii, sprzyjało spękaniu lodu, powstawaniu cieków i zbiorników w obrębie lodu i akumulacji w nich materiału tworzącego następnie kemy i ozy.

\section{Stanowiska badawcze nr 1 i 2 - pagórki kemowe w Owieczkowie}

Pierwsze dwa stanowiska badawcze to pagórki położone w okolicach miejscowości Owieczkowo po obu stronach drogi łączącej Golub-Dobrzyń z Kowalewem Pomorskim (ryc. 2).

Oba wzgórza położone są wzdłuż szlaku odpływu wód lodowcowych, którego osią są kemy w Owieczkowie, oz lisewski i kem w Gaju, (ryc. 2). Wszystkie te formy występują na tle moreny dennej falistej. Ponadto w miejscu tym jest początek rynny jeziora owieczkowskiego, biegnącej poprzecznie (NE-SW) do wspomnianego ciągu odpływu i łączącej się na południu z rynną skępską. Kem zachodni ma kształt płaskiego plateau o powierzchni 23 ha, wysokości względnej 13 m i rozmiarach podstawy 650 na 430 m (Niewiarowski, 1959). Nachylenie stoków w partiach brzegowych dochodzi do 20 stopni. Kem wschodni ma zdecydowaną kulminację i mniejszą powierzchnię (14,5 ha). Jego wysokość względna dochodzi do 12 m, rozmiary podstawy to 550 na 350 m, a stoki nachylone są do 18 stopni. Oba wzgórza zbudowane są z drobnych piasków i mułków, z przewarstwieniami mułków

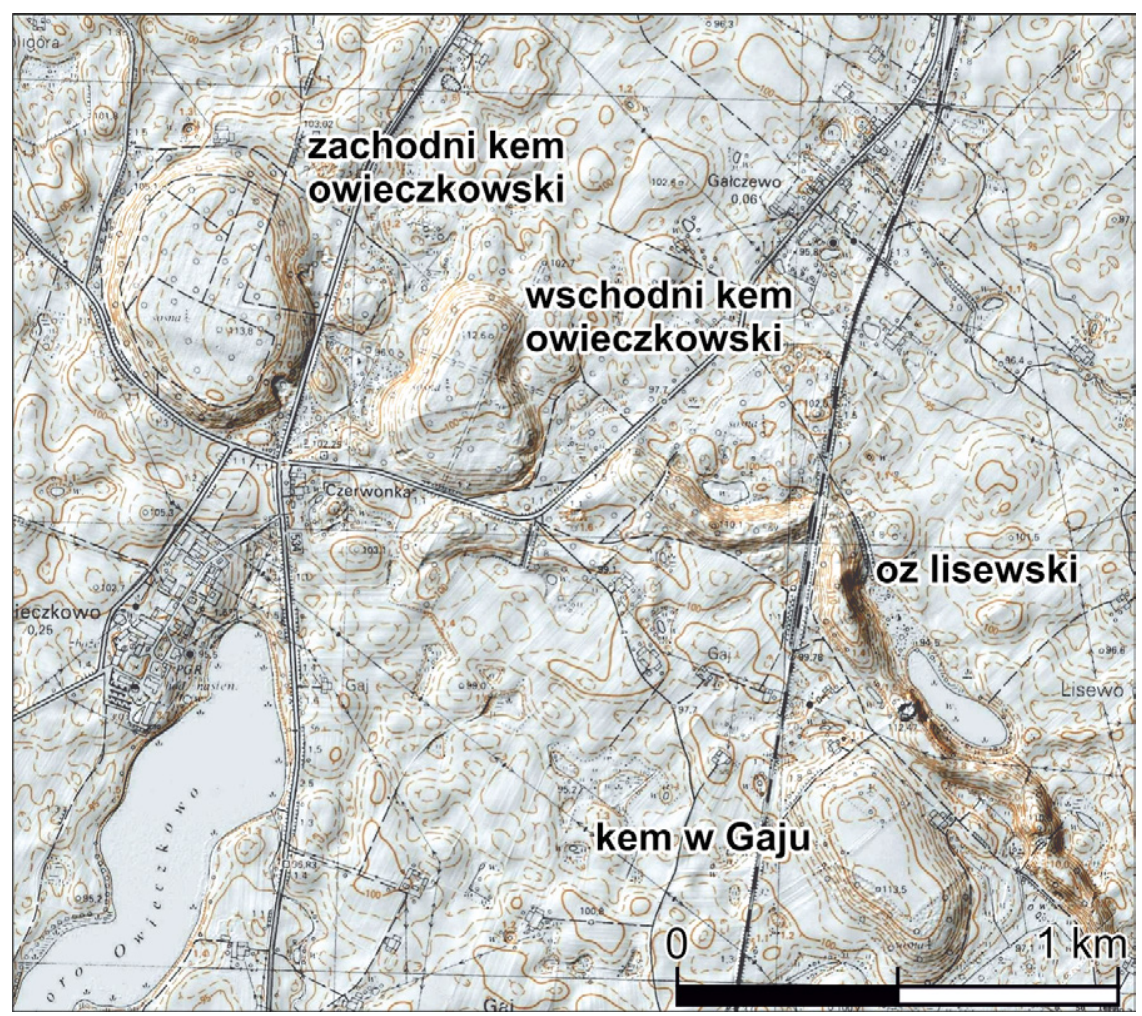

Ryc. 2. Mapa sytuacyjna kemów owieczkowskich i ozu lisewskiego

Situational map of the Owieczkowo kames and Lisewski esker 
ilastych. Niewiarowski wskazuje na przesunięcia pakietów warstw wzdłuż licznych uskoków, które objęły całe pakiety warstw, co świadczy o przemieszczaniu zamarzniętych osadów.

Kemy w Owieczkowie były już przez autora badane w latach 1998-2001 (Lamparski, 2004). Badania te wykonane zostały za pomocą analogowej aparatury georadarowej SIR SYSTEM-3, pod koniec uzupełnionej o przetwornik analogowo-cyfrowy, bez możliwości zastosowania zaawansowanej filtracji i odszumiania sygnału. Podstawową anteną była antena o częstotliwości $300 \mathrm{MHz}$. Wraz z zakupem cyfrowej aparatury GPR z antenami 35 i $400 \mathrm{MHz}$ pojawiła się możliwość weryfikacji wcześniej wykonanych badań, uzyskania większej rozdzielczości warstw przypowierzchniowych (antena $400 \mathrm{MHz}$ ), a także uzyskania większego zasięgu badania (antena $35 \mathrm{MHz}$ ). Wykonano powtórnie wszystkie profile za pomocą nowych anten, a także dodano kilka nowych przekrojów georadarowych (ryc. 3). Zastosowanie anteny $35 \mathrm{MHz}$ pozwoliło osiągnąć spąg osadów glacilimnicznych w centralnej partii zachodniego pagórka. Wykonane w tym miejscu wiercenie wykazało 17 m miąższość piasków drobnych. Na przekroju georadarowym wykonanym w tym miejscu widoczna jest wyraźnie granica pomiędzy osadami piaszczystymi a poniżej leżącą gliną. Ze względu na niski poziom wód gruntowych w czasie badań terenowych, poziom wód gruntowych występował prawdopodobnie bardzo blisko spągu osadów budujących kemy i trudno go odróżnić od granicy facjalnej piasek/glina.

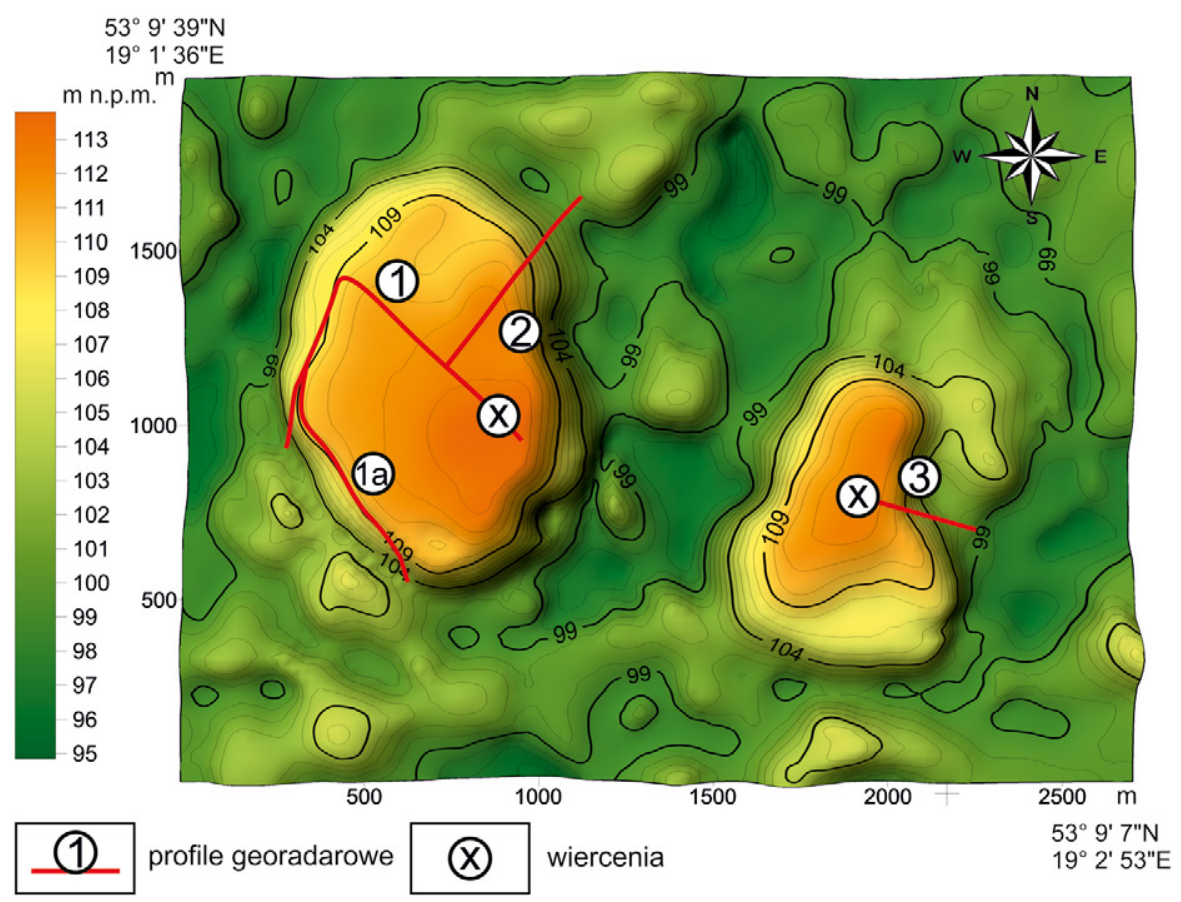

Ryc. 3. Cyfrowy model terenu kemów owieczkowskich (czerwonymi liniami i numerami zaznaczono profile georadarowe)

Digital terrain model of the Owieczkowo kame hills (GPR profiles marked with red lines and numbers) 
Przeprowadzone badania georadarowe zachodniego pagórka kemowego w Owieczkowie polegały na przecięciu całej formy liniami profili georadarowych od centralnej kulminacji po partie krawędziowe oraz za pomocą anten o częstotliwościach $35 \mathrm{MHz}$ i $400 \mathrm{MHz}$. Łącznie wykonano 6 profili (nr 1, 1a i 2 dla obu częstotliwości), osiągając miąższości badania odpowiednio 20 i 7 m w pokrywających się transektach. Wyniki pomiarów z zastosowaniem anteny o częstotliwości $35 \mathrm{MHz}$ dały wgląd w całą masę osadów drobnopiaszczystych leżących na glinie morenowej aż do ich spągu, zaś pomiary za pomocą anteny $400 \mathrm{MHz}$ pozwoliły uzyskać precyzyjny obraz $7 \mathrm{~m}$ przypowierzchniowej warstwy osadów piaszczysto-mułkowych z występującymi w ich obrębie przewarstwieniami osadów drobniejszych, tj. mułków piaszczystych oraz ich zaburzeniami i przemieszczeniami (ryc. 4). Badania potwierdziły występowanie w pagórkach kemowych przewarstwień mułkowo-ilastych, upadających ku centrum form i wychodzących ku górze przy ich krawędziach. Obraz struktur, jaki został uzyskany na podstawie badań georadarowych był bardzo szczegółowy i obejmował kilka kategorii facjalnych (w sensie facji georadarowych). Zaobserwowano strefy spokojniejszej sedymentacji (w sensie dynamiki procesów) ograniczone w planie poziomym strefami występowania licznych anomalii geofizycznych interpretowanych jako głazy i materiał spływowy.

Na rycinie 4 (zachodni kem owieczkowski) zwracają uwagę liczne anomalie interpretowane jako uskoki. Ich interpretacja opiera się na obserwacji na profilach georadarowych pionowych przesunięć pasm będących w opinii autora przewarstwieniami

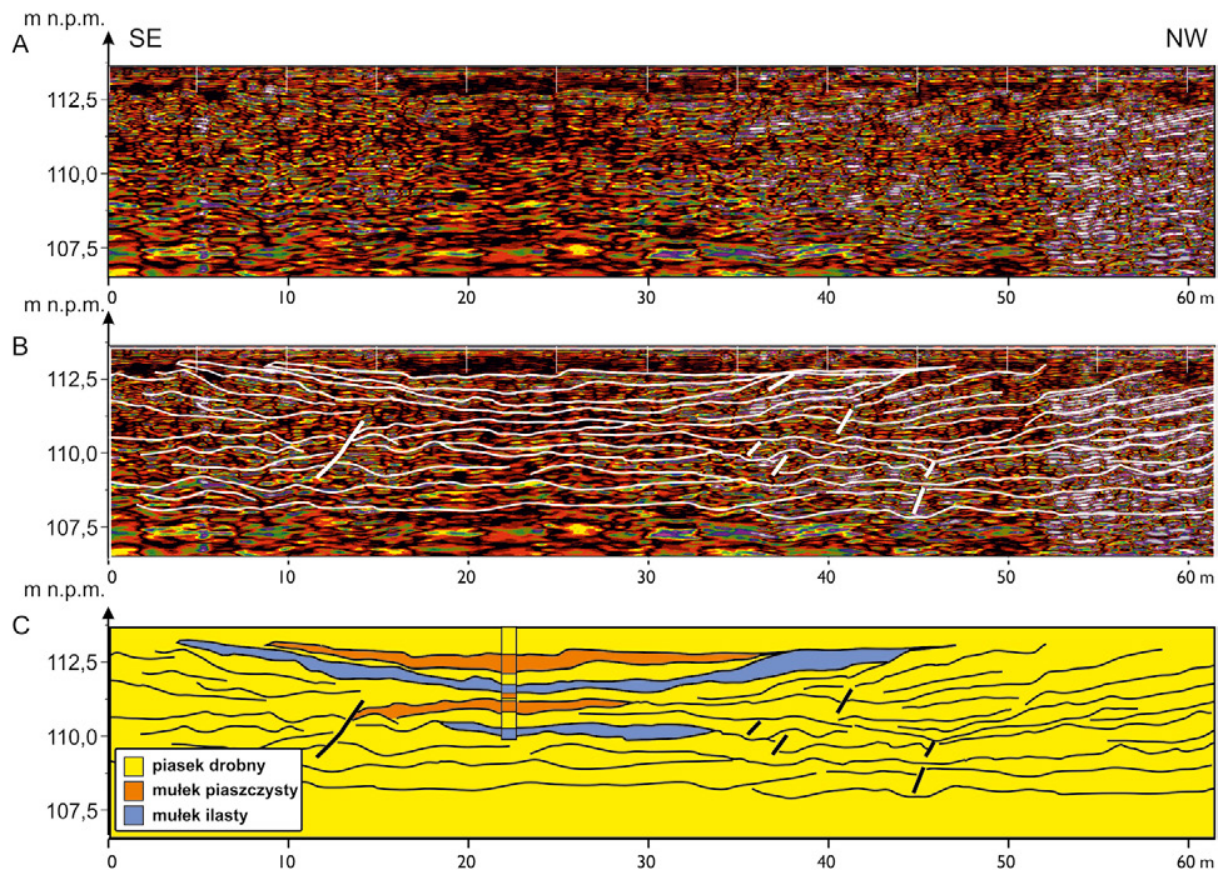

Ryc. 4. Struktura anomalii geofizycznych w centralnej partii zachodniego pagórka kemowego w Owieczkowie A - surowy obraz georadarowy, B - układ anomalii geofizycznych, C-interpretacja Structure of geophysical anomalies in the central part of the western Owieczkowo kame hill $A$ - raw GPR data, B - configuration of geophysical anomalies, $C$-interpretation 
mułkowymi w masie osadu piaszczystego. Korelacja mułkowych przewarstwień z liniami na przekrojach georadarowych została udowodniona na podstawie wierceń wykonanych w trakcie poprzednich badań kemów (Lamparski, 2004). Istnienie uskoków sprzyjałoby infiltracji wody w osadzie i wytrącaniu tlenków i wodorotlenków żelaza, które w postaci scementowanych warstw są łatwo rejestrowane za pomocą metody georadarowej (Czuryłowicz i inni, 2014; Lejzerowicz i inni, 2014). Obecność licznych uskoków o wielkości zrzutu do 0,5 m w zachodnim kemie owieczkowskim potwierdziły wcześniejsze obserwacje W. Niewiarowskiego w istniejącej wówczas dużej odkrywce przy wschodniej krawędzi kemu (Niewiarowski, 1959). Odkrywka ta obecnie zarośnięta jest gęstym lasem, ale jej położenie jest nadal czytelne w terenie. Niewiarowski na podstawie własnych obserwacji miał podstawy sądzić, że uskoki na pewno występują w części krawędziowej kemu, a środek w jego ocenie był niezaburzony. Tymczasem nieciągłości na profilach georadarowych zachodniego kemu owieczkowskiego (ryc. 4 oraz fragment profilu nr 1 widoczny na ryc. $6 \mathrm{~A}$ ), interpretowane przez autora jako uskoki występują zarówno w strefie przykrawędziowej, jak i centralnie w kulminacji pagórka. Płaszczyzny uskoków dochodzą do samego spągu osadów. Ich obecność w całej masie osadu świadczy o sypaniu osadów dennych jeziora na podłożu lodowym.

Układ anomalii geofizycznych na profilach georadarowych przybiera postać koncentrycznych makrostruktur. Struktury mają ułożenie horyzontalne w centralnych partiach plateau i wychodzą ku górze koncentrycznie w miarę oddalania się od kulminacji. Anomalie interpretowane jako osady spływowe obserwowane są głównie w brzeżnych partiach pagórka. W kulminacji zachodniego pagórka kemowego w Owieczkowie spąg osadów piaszczysto-mułkowych został określony metodą GPR i potwierdzony wierceniem na okoto $17 \mathrm{~m}$ (ryc. 6).

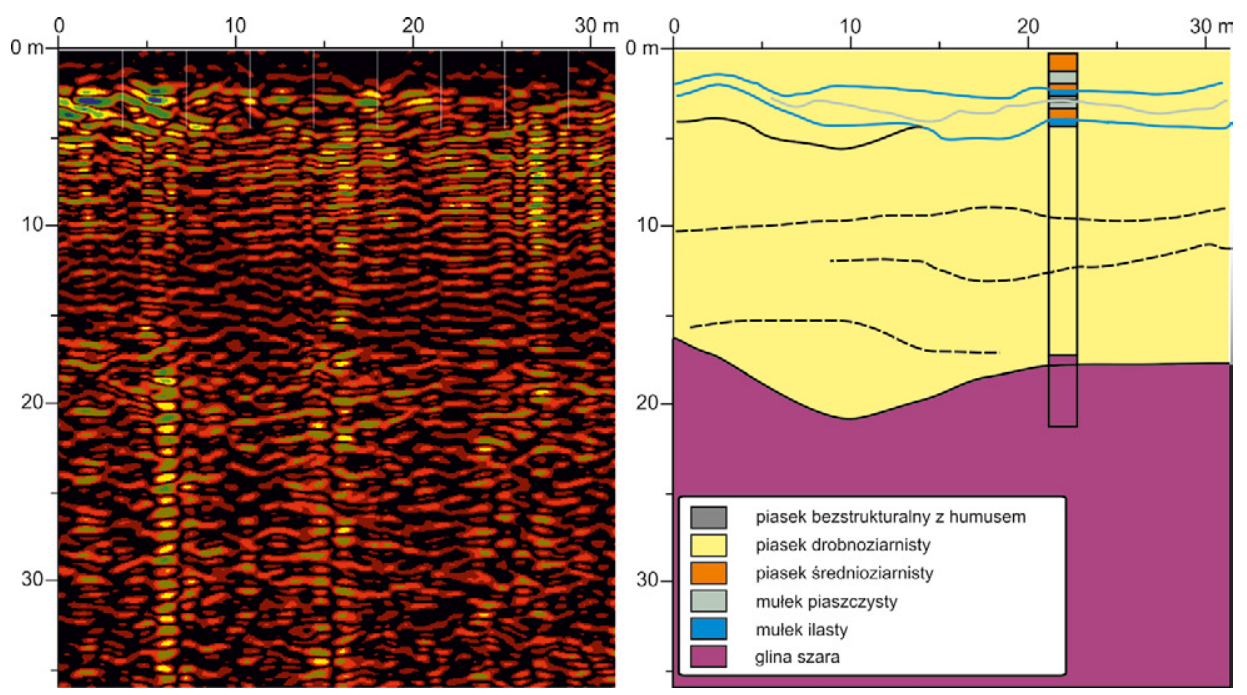

Ryc. 5. Interpretacja anomalii geofizycznych w kulminacji zachodniego kemu owieczkowskiego w porównaniu z wierceniem

Interpretation of geophysical anomalies at the culmination point of the western Owieczkowo kame compared with drilling 
W podobny sposób przeprowadzono również badania wschodniego kemu owieczkowskiego (ryc. 3 - profil nr 3). Układ pasm, tworzących makrostruktury 1. rzędu został już wcześniej rozpoznany jako sekwencje przewarstwień mułkowych w osadach piaszczystych (Lamparski, 2004) (ryc. 6B). Cały profil nr 3 poprzecinany jest prawie horyzontalnie ułożonymi liniami. Linie te zapadają przeważnie w kierunku centrum formy. Tu również w centralnej części kemu pasma anomalii georadarowych układają się horyzontalnie. To ułożenie odbić radarowych szczególnie widoczne jest w okolicach 170-200 mb długości profilu (ryc. 6B). Stosunkowo płytko pod powierzchnią kemu, w kilku miejscach, występują wyraźne wyniesienia granicy osadów w postaci silnie zaburzonych struktur. Zaburzenia te zaobserwować można około $150 \mathrm{mb}$ profilu $\mathrm{nr} 3$, a także pomiędzy 120 a $135 \mathrm{mb}$ oraz w okolicach 50 i $95 \mathrm{mb}$. Prawdopodobnie są to nagromadzenia materiału spływowego i głazów. Od podstawy kemu (0 mb) do 130 metra w podłożu występuje charakterystyczny dla glin zespół anomalii w kształcie odwróconych wzajemnie nakładających się hiperboli. Są to niewątpliwie odbicia fal elektromagnetycznych od większych głazików i głazów. Prawdopodobnie w tym rejonie spąg osadów piaszczysto-mułkowych i granica z gliną morenową mają postać horyzontalnej powierzchni.

Zastanawia odmienny obraz anomalii georadarowych w obu kemach, leżących przecież bardzo blisko siebie. Uzyskane wyniki wskazują na odmienny sposób wykształcenia się układu makrostruktur w obu pagórkach (ryc. 6). Jest to prawdopodobnie związane z ich morfometrią. Kem zachodni to rozległe plateau. Wykazuje on typowy dla kemów glacilimnicznych układ warstw lekko zapadających w kierunku centrum formy. W całej masie osadu widoczne są liczne uskoki o przebiegu chaotycznym, związane z osiadaniem formy po wytopieniu podłoża lodowego. Kem wschodni jest mniejszy, z wyraźną kulminacją i blisko położonymi krawędziami jeziora lodowego. Sedymentacja następowała w sposób bardziej zróżnicowany, w jego części kulminacyjnej układ warstw przybiera ułożenie horyzontalne (prawa, zachodnia strona na ryc. 6B), w części wschodniej pagórka

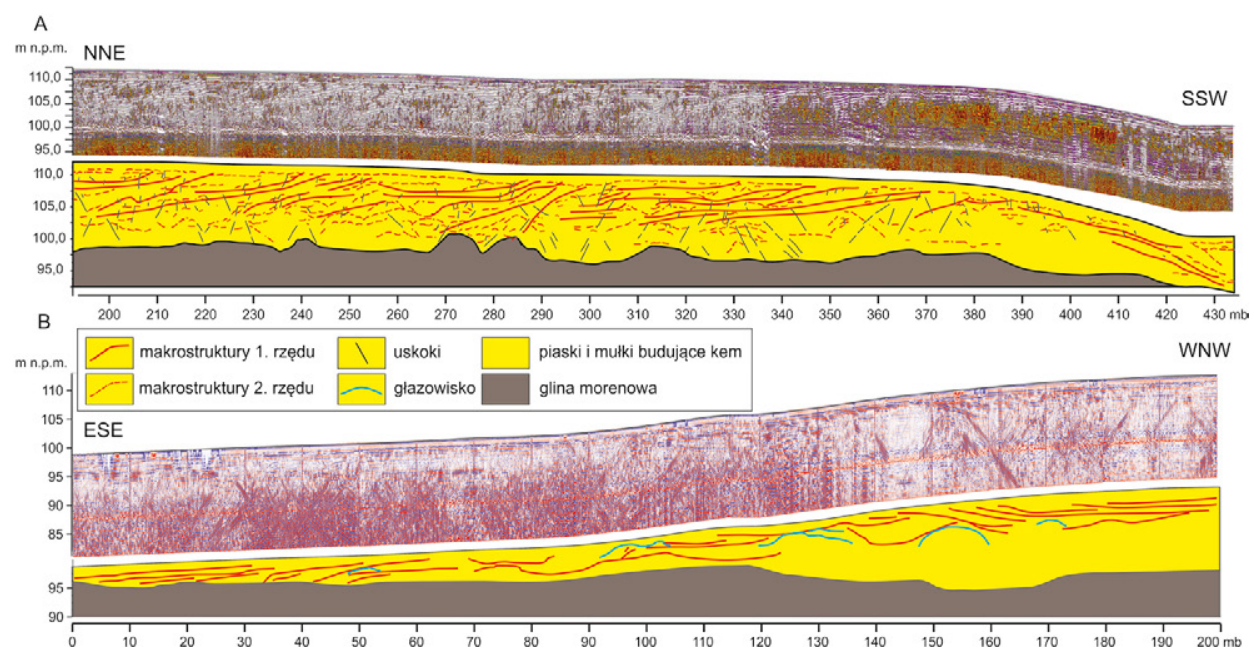

Ryc. 6. Układ anomalii geofizycznych w zachodnim pagórku kemowym w Owieczkowie - 190-435 mb przekroju 1 z ryc. 3 (A) i we wschodnim pagórku kemowym w Owieczkowie - przekrój 3 z ryc. 3 (B) Configuration of geophysical anomalies in the western (A) and eastern (B) Owieczkowo kame hill 
warstwy wyraźnie układają się w sposób nachylony, wskazując na spływowy charakter tego osadu. Materiał spływowy akumulował się jednocześnie z akumulacją glacilimniczną dawnego jeziora, z blisko leżących krawędzi jeziora zsuwał się materiał wytapiany z lodu i wzbogacał sekwencje piaszczysto-mułkowe w materiał głazowy, o czym świadczą wypełnienia powstałych w końcowej fazie lokalnych obniżeń, powstałych pomiędzy głazowiskami i materiałem spływowym. Niestety duża ilość anomalii generowanych przez głazy w postaci odwróconych hiperboli zamazała obraz ewentualnych uskoków we wschodnim kemie, zatem nie uwzględniono ich w interpretacji. W trakcie poprzednich badań kemów owieczkowskich (Lamparski, 2004) rezultaty płytki wierceń wykonanych sondą ręczną pozwoliły na kalibracje obrazów georadarowych obu kemów zgodnie z litologią budujących je warstw.

\section{Stanowisko badawcze nr 3 - pagórek kemowy w Zapluskowęsach}

Stanowisko badawcze nr 3 to kem w Zapluskowęsach. Jest to izolowane wzgórze w okolicach miejscowości Zapluskowęsy, położone najdalej na północ z badanych form. Położone w obrębie wysoczyzny morenowej płaskiej (ryc. 1) występuje samotnie, z dala od rynien i ozów. Wzgórze wznosi się na wysokość 12 m, jego powierzchnia wynosi 11 ha, a rozmiary podstawy 480 na 300 m. Stoki nachylone są do 9 stopni (ryc. 7). Budowa geologiczna zasadniczo nie odbiega od wzgórz owieczkowskich. Budują je piaski drobne i bardzo drobne z przewar-

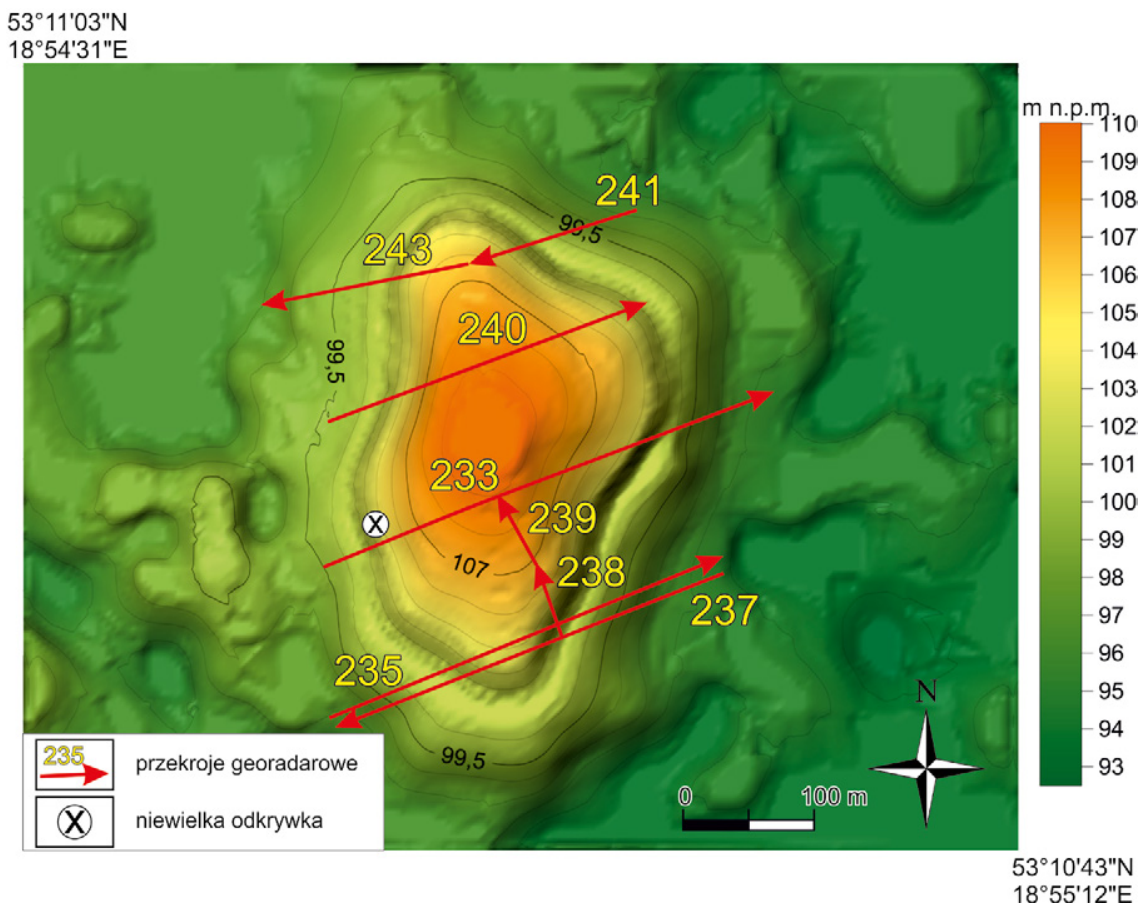

Ryc. 7. Rozmieszczenie przekrojów georadarowych na obszarze pagórka kemowego w Zapluskowęsach (na żółto oznaczono numery przekrojów)

Location of GPR cross-sections in the area of the Zapluskowęsy kame hill (section numbers in yellow) 
stwieniami mułków (ryc. 8). Niestety brak większych odsłonięć nie pozwala na pełniejszy wgląd w budowę formy. Płytkie wkopy w kilku miejscach pozwoliły jedynie zaobserwować bardzo dużą jednorodność osadów przypowierzniowych (pod względem granulometrycznym oraz właściwości dielektrycznych). W jednorodnych osadach drobnopiaszczystych występują również liczne, ale niewielkiej miąższości wytrącenia związków żelaza (ryc. 8).

Badania georadarowe pagórka kemowego w Zapluskowęsach zostały przeprowadzone za pomocą takiej samej aparatury georadarowej (SIR SYSTEM-2000, anteny $35 \mathrm{MHz}$ i $400 \mathrm{MHz}$ - zasięgi odpowiednio do 20. m i do 6-8. m). Kalibrację skali głębokości przeprowadzono metodą pomiaru stałej dielektrycznej FDR (ang. Frequency Domain Reflectometry) w pobliskim niewielkim odsłonięciu. Ogółem wykonano około 1200 m bieżących przekrojów georadarowych (ryc. 7).

Pomiary wartości stałej dielektrycznej w odsłonięciu przypowierzchniowej warstwy osadu wykazały bardzo dużą jej jednorodność pod względem parametrów elektrycznych. Stała dielektryczna we wszystkich punktach pomiarowych (ryc. 8) mieściła się w zakresie 4,3-4,5. Tak duża jednorodność elektryczna osadu określa dużą pewność w kalibracji pionowej skali głębokości w metodzie georadarowej. Przyjęto zatem, że w całej miąższości badanych osadów występują podobne prędkości przemieszczania się fal elektromagnetycznych i skala czasowa profilogramów georadarowych jest wprost proporcjonalna do skali rzeczywistej głębokości.

Fragment przekroju georadarowego $\mathrm{nr}$ 240, wykonanego za pomocą anteny o częstotliwości $400 \mathrm{MHz}$ i biegnącego na północ od kulminacji przedstawiono na rycinie 9. Jest to kulminacyjny odcinek przekroju o długości w przybliżeniu 73 metrów i miąższości

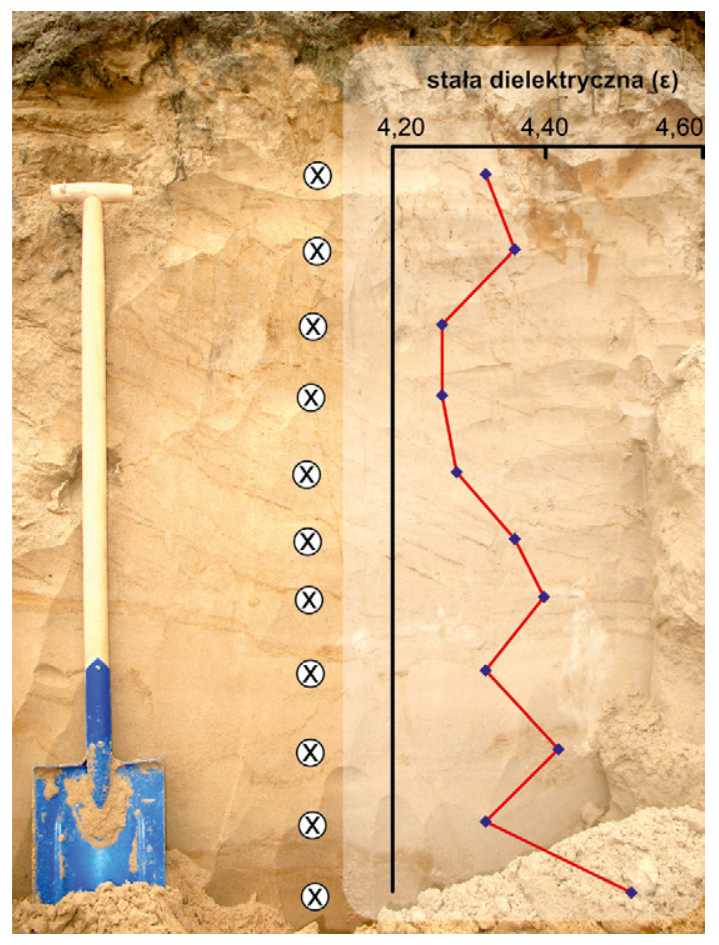

Ryc. 8. Miejsca pomiarów stałej dielektrycznej w przypowierzchniowej warstwie osadów kemowych Places of measurement of the dielectric constant in the subsurface layer of kame sediments 


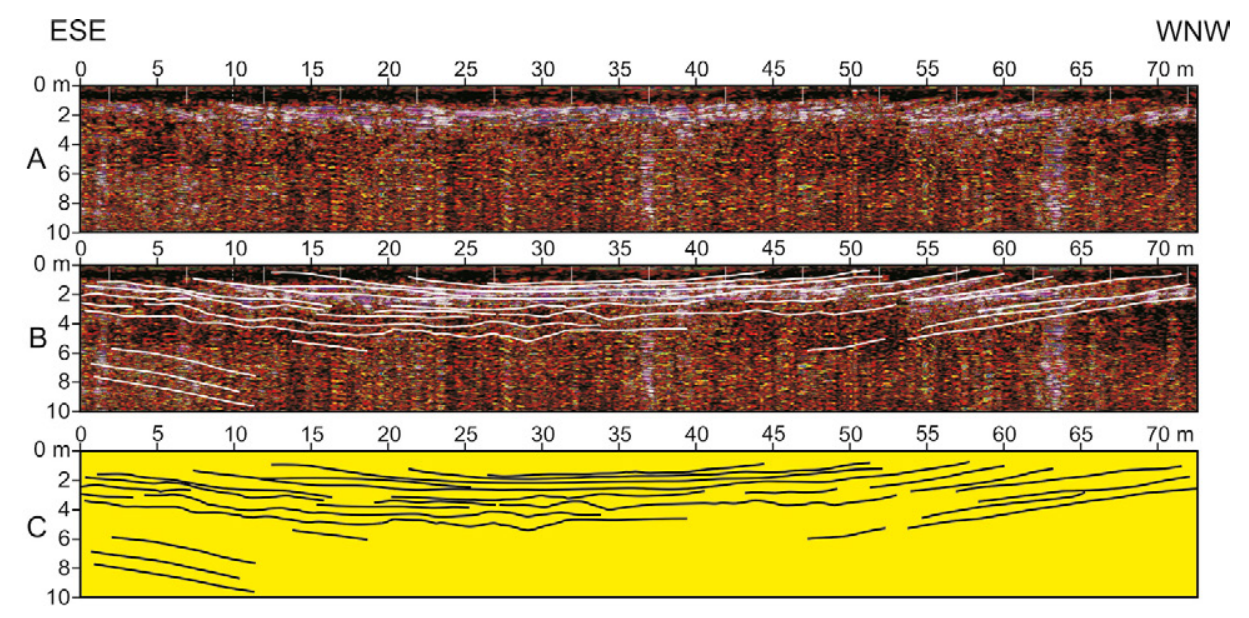

Ryc. 9. Centralna część kemu w Zapluskowęsach

A - przekrój georadarowy (nr 240 na ryc. 7), B - przekrój georadarowy z naniesioną interpretacją, C - interpretacja układu makrostruktur Central part of the Zapluskowęsy kame hill

A - GPR section (No. 240 in Fig. 7), B - GPR section with interpretation, C-interpreted configuration of macrostructures

10 metrów. Ze względu na jednorodność osadu nie wydzielono jednostek litofacjalnych. Wyznaczone linie reprezentują prawdopodobnie układ przewarstwień mułkowych tworzących większą makrostrukturę typową dla form kemowych (Karczewski, 1971; Klajnert, 1978; Jaksa, 2003). Podobnie jak w kilku sąsiednich pagórkach kemowych układ warstw lekko zapada w kierunku centrum formy, w kulminacji formy tworząc układ horyzontalny. Prawdopodobnie ich układ jest urozmaicony drobnymi uskokami, jednak ze względu na niewystarczającą rozdzielczość metody przy tak jednorodnym materiale, nie zostały one zaobserwowane. Warstwy tworzące makrostrukturę formy tworzą typowy układ koncentryczny. Anomalie geofizyczne na całej długości przekroju są dobrze czytelne do około 6 metrów pod powierzchnią terenu.

Wzdłuż wyznaczonych linii przekrojowych przeprowadzono również sondowania georadarowe anteną o częstotliwości $35 \mathrm{MHz}$, uzyskując prawdopodobny obraz spągu osadów piaszczystych na głębokości około 15-16 metrów poniżej kulminacji.

\section{Stanowisko badawcze nr 4 - pagórek kemowy w Piątkowie}

Stanowisko badawcze nr 4 to wzgórze kemowe położone w miejscowości Piątkowo, wśród kilku wzniesień określonych przez W. Niewiarowskiego (1959) jako kemy oraz moreny martwego lodu (ryc. 1). Forma położona jest na linii wyznaczonej przez oz lisewski, wzgórza w Owieczkowie i Dylewie, najdalej na północ spośród form kemowych i ozowych tworzących ciąg odpływu, najbliżej południowego krańca odnogi rynny wąbrzeskiej. Jej powierzchnia wynosi około 6,5 ha, wysokość względną $12 \mathrm{~m}$, a podstawa ma rozmiary 300 na $250 \mathrm{~m}$. Nachylenie stoków dochodzi do 10 stopni.

Budowa geologiczna kemu w Piątkowie jest doskonale widoczna w odkrywce o wysokości 10 metrów i długości około 120 metrów znajdującej się przy południowo zachod- 
niej krawędzi formy (ryc. 10). Odsłonięcie dokumentuje około dziesięciometrową serię piasków drobnoziarnistych z licznymi przewarstwieniami mułków piaszczystych i mułków ilastych (fot. 2). Generalnie utwory te charakteryzują się warstwowaniem horyzontalnym, lokalnie ripplemarkowym. W centralnej części odsłonięcia pakiety warstw mułkowych i ilastych tworzą struktury głównie horyzontalne, natomiast bliżej krawędzi bocznych warstwy wychodzą ku górze. W masie osadu występują bardzo nieliczne uskoki normalne. Częściej są to mikrouskoki o amplitudzie rzędu kilku cm, rzadziej o amplitudzie 20-30 cm. Te ostatnie występują przy krawędzi formy, w strefach występowania na powierzchni materiału spływowego i powstały raczej wskutek deformacji spowodowanych spływami niż wytapianiem lodu z podłoża kemu. Na powierzchni formy miejscami zaobserwować można około półmetrowej miąższości warstwę diamiktonu, prawdopodobnie o charakterze spływowym.

Na fotografii odsłonięcia zaznaczono charakterystyczne sekwencje granic osadów, które mogą być istotne z punktu widzenia zmienności parametrów dielektrycznych (ryc. 11). Zaznaczono znaczniejsze warstwy mułkowo-ilaste oraz wytrącenia związków żelaza. Interpretacja anomalii geofizycznych przedstawiona jest w dolnej części (ryc. 11C). Występuje stosunkowo duża zgodność układu anomalii geofizycznych z układem przewarstwień mułkowo-ilastych. Zgodność ta szczególnie widoczna jest przy centralnym układzie horyzontalnym warstw oraz przy warstwach wychodzących ku górze bliżej krawędzi formy. Brak korelacji w niektórych miejscach może wynikać z faktu, że linia przekroju georadarowego

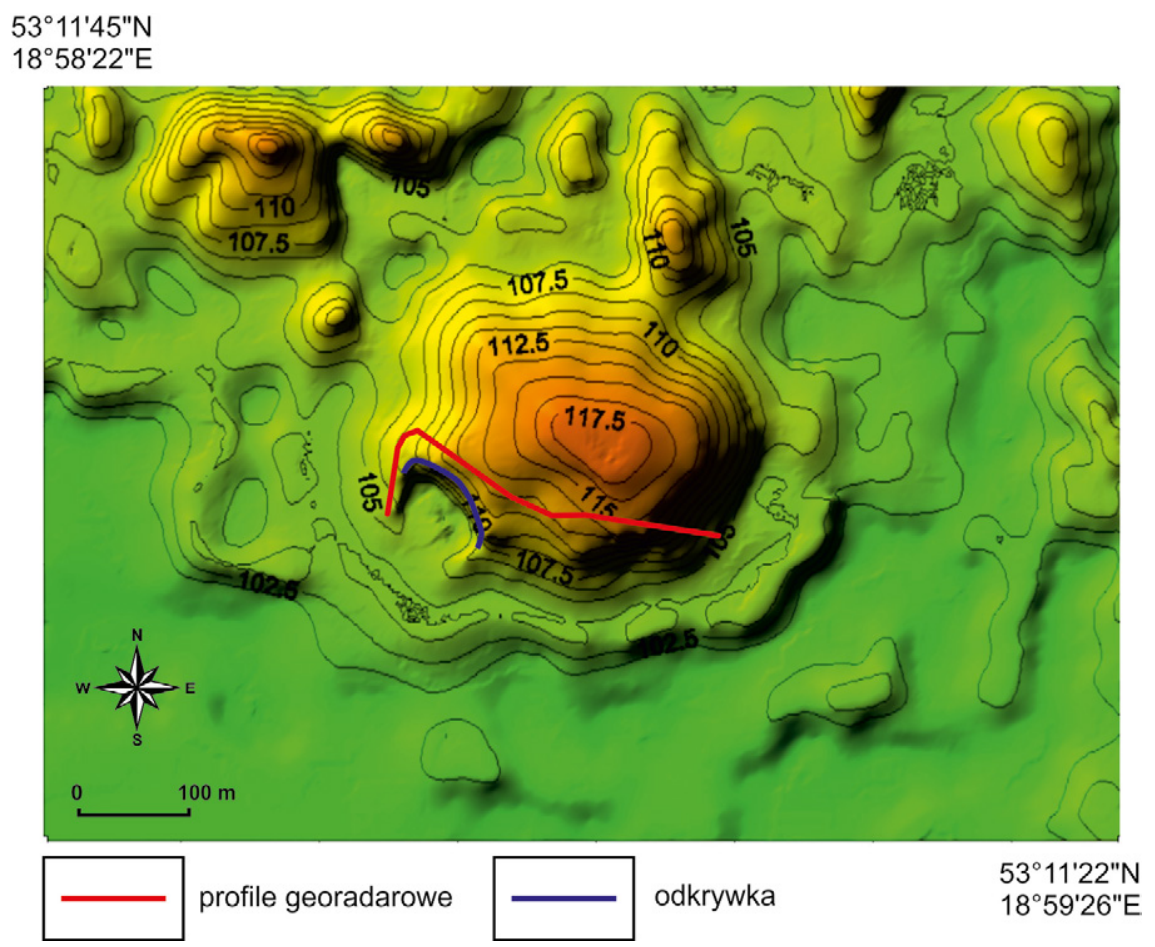

Ryc. 10. Cyfrowy model terenu pagórka kemowego w Piątkowie z zaznaczoną linią przekroju GPR Digital terain model of the Piqtkowo kame hill showing the line of the GPR cross section 

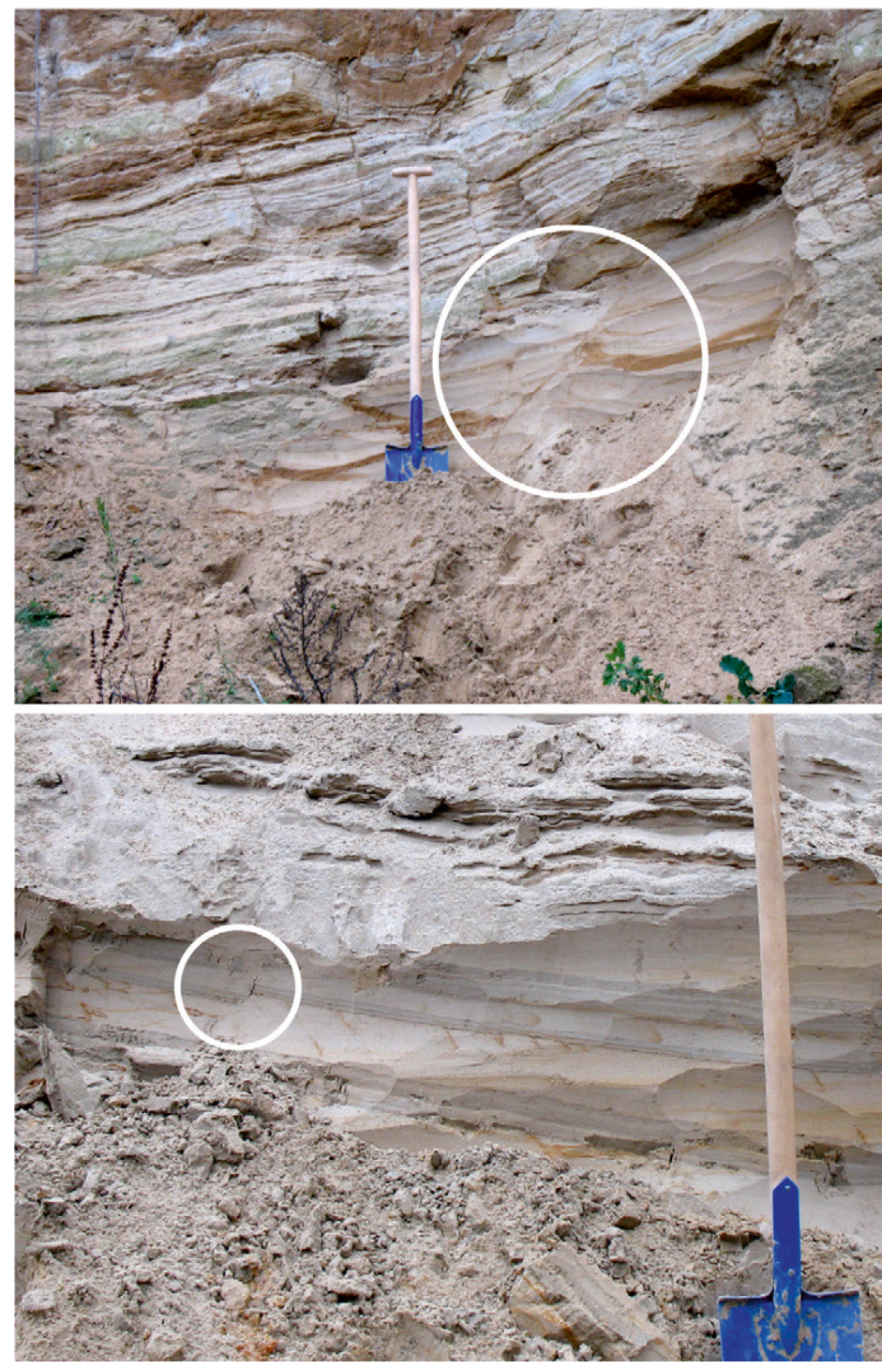

Fot. 2. Budowa geologiczna kemu w Piątkowie (białymi okręgami zaznaczono drobne uskoki normalne) (fot. Piotr Lamparski)

Geological structure of the Piqutkowo kame (small normal faults are marked with white circles)

znajdowała się w odległości 2-3 metrów od krawędzi skarpy odsłonięcia, a na powierzchni można zaobserwować niewielkiej miąższości warstwę gliny spływowej, tłumiącej fale elektromagnetyczne. Brak rejestracji uskoków na profilach radarowych wynika prawdopodobnie z ich nielicznego występowania oraz, w przypadku nielicznych widocznych uskoków w odsłonięciu, z odsunięcia linii badań od krawędzi odkrywki.

Układ makrostruktur w całej masie formy jest wyraźnie koncentryczny i wskazuje na stosunkowo spokojną sedymentację osadów. Brzeżne partie kemu przykryte są około 

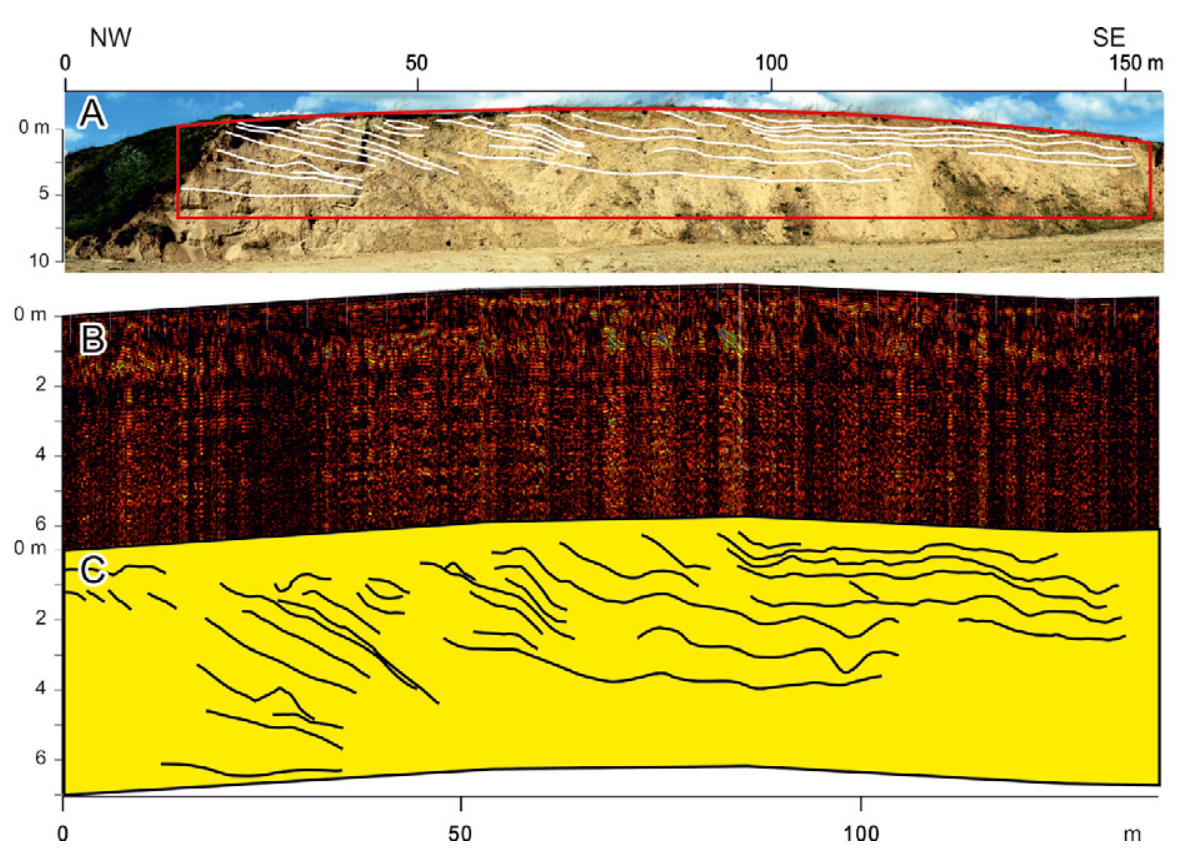

Ryc. 11. Fragment profilu georadarowego wykonanego w bezpośrednim sąsiedztwie odsłonięcia w kemie piątkowskim

A - odsłonięcie z naniesionymi głównymi makrostrukturami, B - przekrój GPR (czerwony obrys na ryc. 11A), C-układ anomalii geofizycznych

Fragment of a GPR profile made in the direct vicinity of the outcrop on the Piqtkowski kame hill A-outcrop with interpretation of main macrostructures, B - GPR cross-section (red outline on Fig. 11A), C-configuration of geophysical anomalies

metrowej miąższości gliną spływową, która cienką warstwą rozciąga się również na wyższe partie wzgórza. Pomimo tego przykrycia badanie osadów glacilimnicznych za pomocą metody georadarowej jest możliwe i efektywne.

\section{Podsumowanie}

Możliwości, jakie daje metoda georadarowa w zakresie tworzenia szybkich modeli litostratygraficznych osadu, są potencjalnie bardzo duże. Z punktu widzenia poznawczego jest to dużym ułatwieniem i skróceniem procedur uzyskiwania informacji o osadzie, zaś z punktu widzenia ekonomii działań, dużym ograniczeniem kosztów i czasu badań w płytkiej geologii obszarów o powierzchniowym występowaniu luźnych osadów klastycznych. Na uwagę zasługuje również możliwość wykorzystania rezultatów badań georadarowych we wspomaganiu kartowania geologicznego.

Największą zaletą metody GPR jest możliwość zaobserwowania w dużej skali struktury osadów budujących kemy. Wobec braku rozległych odkrywek prospekcja geofizyczna form powierzchni Ziemi jest o tyle pomocna, o ile jesteśmy w stanie przełożyć wyniki badań geofizycznych na rzeczywisty układ litostratygraficzny osadów budujących daną formę. Przedstawione w artykule badania kemów wpisują się w nurt tworzenia stratygrafii rada- 
rowej, będącej istotnym wsparciem bezpośrednich badań geologicznych (Huggenberger i inni, 1994; Van Overmeeren, 1998; Beres i inni, 1999; Overgaard i Jakobsen, 2001; Jakobsen i Overgaard, 2002; Neal, 2004; Lejzerowicz i inni, 2014; Żuk i Sambrook Smith, 2015; Lejzerowicz i inni, 2018). Pokazują także potencjał badawczy metody GPR przy określaniu genezy formy. Dyskusja dotycząca sposobów powstania, a nawet definicji kemów trwa w literaturze od lat (Niewiarowski, 1959; 1961; Karczewski, 1971; Klajnert, 1978; Jaksa, 2003; Terpiłowski, 2008). Przedstawione badania nie są na tyle kompleksowe, żeby jednoznacznie rozstrzygać w tej materii, jednak dają przesłanki do uściślenia niektórych ustaleń poprzednich badaczy. Przykładem niech będzie zaobserwowanie licznych uskoków w całej masie zachodniego kemu owieczkowskiego (ryc. 6A), co świadczy o deponowaniu kemu na lodzie, a nie na podłożu mineralnym (Niewiarowski, 1959).

Obszar, który jest przedmiotem badań tego artykułu, jest przez W. Niewiarowskiego (1959) określany jako strefa martwego lodu ze względu na charakterystyczny zespół form (moreny martwego lodu, kemy, ozy). Podobnie jak współcześni badacze (Terpiłowski, 2008), Niewiarowski wskazuje na wagę wyniesień powierzchni podczwartorzędowej w tworzeniu spękań w lądolodzie i sprzyjaniu tworzeniu się form kemowych ponad takimi wyniesieniami. Wydaje się, że również tu była to jedna z przyczyn powstawania jezior w masie lodu, które po wypełnieniu osadami glacjolimnicznymi i wytopieniu ścian lodowych stały się formami kemowymi.

Dużą zaletą metody GPR jest możliwość rozpoznania w formach glacilimnicznych układów makrostrukturalnych osadów. Rozpoznanie to pozwala z dużym prawdopodobieństwem ocenić genezę formy, szczególnie w kontekście ustalenia jej pozycji w strefie marginalnej lądolodu. Niezwykle obiecująca jest również możliwość określenia za pomocą georadaru miąższości osadów drobnoklastycznych leżących na glinie, a zatem określenia sposobu zakorzenienia kemów.

Opisane pokrótce wyniki badań wybranych stanowisk potwierdziły dużą przydatność metody georadarowej w rozpoznaniu płytkiej litostratygrafii osadów klastycznych. Jednak należy podkreślić, że nie może ona stanowić jedynej metody rozpoznania budowy geologicznej form i osadów. Niejednoznaczności interpretacyjne powodują, że metoda GPR powinna być metodą uzupełniającą badania bezpośrednie, a nie ich alternatywą. Badania georadarowe dają szczególnie zbliżony do rzeczywistego obraz osadów, gdy te występują w postaci jednorodnej pod względem parametrów elektrycznych. Takimi idealnymi do badań georadarowych osadami są suche piaski i mułki. Takie też osady budowały w większości badane pagórki kemowe.

Ryciny, pod którymi nie zamieszczono źródła, są opracowaniami własnymi autora artykułu.

Autor dziękuje Recenzentom, których uwagi zdecydowanie przyczyniły się do ulepszenia artykułu. Większość przedstawionych w tym artykule badań terenowych sfinansowano z projektu badawczego MNiSzW nr N N306 281235 „Geneza wybranych form wodnolodowcowych na Niżu Polskim w świetle geofizycznych badań georadarowych”. 


\section{Piśmiennictwo}

Annan A.P., Davis J.L., 1976, Impulse radar soundings in permafrost, Radio Science, 11, s. 383-394. https://doi.org/10.1029/RS011i004p00383.

Annan A.P., Davis J.L., 1977, Radar range analysis for geological materials, Geological Survey of Canada, Report of Activities, Part B, Paper 77-1B, s. 117-124.

Beiping J., Mitsuno T., Akae T., Nagahori K., 1996, Measurement of Soil Dielectric Constant by Frequency Domain Reflectometry and its Application to Soil Moisture Measurement of Specified Depth, Transactions of The Japanese Society of Irrigation, Drainage and Reclamation Engineering, 182, s. 201-206.

Beres M., Green A.G., Huggenberger P., Horstmeyer H., 1995, Mapping the architecture of glaciofluvial sediments with 3-D georadar, Geology, 23, s. 1087-1090.

Beres M., Huggenberger P., Green A.G., Horstmeyer H., 1999, Using two- and three- dimentional georadar methods to characterize glaciofluvial architecture, Sedimentary Geology, 129, s. 1-24.

Błaszkiewicz M., Kordowski J., Objaśnienia do Szczegółowej Mapy Geologicznej Polski w skali 1: 50 000, ark. Kowalewo Pomorskie (322), Centralne Archiwum Geologiczne PIG, Warszawa, materiały niepublikowane.

Borkowski W., 1990, Results of Subsurface Interface Radar. Geophysical studies of the Krzemionki banded flint mines, Archeometry, 90, s. 740-746.

Busby J.P., Merritt J.W., 1999, Quaternary deformation mapping with ground penetrating radar, Journal of Applied Geophysics, 41, s. 75-91. https://doi.org/10.1016/S0926-9851 (98)00050-0.

Czuryłowicz K., Lejzerowicz A., Kowalczyk S., Wysocka A., 2014, The origin and depositional architecture of Paleogenequartz-glauconite sands in the Lubartów area, eastern Poland, Geological Quarterly, 58, 1, s. 125-144. https://doi.org/10.7306/gq.1137.

Davis J.L., Annan A.P., 1989, Ground penetrating radar for high resolution mapping of soil and rockstratigraphy, Geophysical Prospecting, 37, s. 531-551. https://doi.org/10.1111/j.1365-2478.1989. tb02221.x.

Drozd M., Trzepla M., 2005a, Objaśnienia do Szczegółowej Mapy Geologicznej Polski w skali 1: 50 000, ark. Wąbrzeźno (283). Centralne Archiwum Geologiczne PIG, Warszawa.

Drozd M., Trzepla M., 2005b, Objaśnienia do Szczegółowej Mapy Geologicznej Polski w skali 1: 50 000, ark. Ksiq̨żki (284), Centralne Archiwum Geologiczne PIG, Warszawa.

Huggenberger P., Meier E., Pugin A., 1994, Ground-probing radar as a tool for heterogeneity estimation in gravel deposits: advances in data-processing and facies analysis, Journal of Applied Geophysics, 31, 171-184. https://doi.org/10.1016/0926-9851 (94)90056-6.

Jakobsen P.R., Overgaard T., 2002, Georadar facies and glaciotectonic structures in ice marginal deposits, northwest Zealand, Denmark, Quaternary Science Reviews, 21, s. 917-927. https://doi. org/10.1016/S0277-3791 (01)00045-2.

Jaksa A., 2003, O badaniach kemów w Polsce, [w:] B. Gruszka (red.), Kemy i ozy: stary problem w nowym, sedymentologicznym ujęciu: Terenowe Warsztaty Sedymentologiczne 08-12 września 2003, Uniwersytet Ślqski, Uniwersytet Łódzki, Sosnowiec, s. 3-15.

Jol H.M., Young R., Fisher T.G., Smith D.G., Meyers R.A., 1996, Ground Penetrating Radar of eskers, kame terraces, and moraines: Alberta and Saskatchewan, Canada, [w:] GPR'96, 6th International Conference on Ground Penetrating Radar, Proceedings, Tohoku University, Sendai, Japan, s. 439-443.

Karczewski A., 1971, Zmienność litologiczna i strukturalna kemów Pomorza Zachodniego a zagadnienie ich klasyfikacji, Prace Komisji Geograficzno-Geologicznej, Poznańskie Towarzystwo Przyjaciół Nauk, 11, 3, s. 1-57. 
Klajnert Z., 1978, Zanik lodowca warciańskiego na Wysoczyźnie Skierniewickiej i jej północnym przedpolu, Acta Geographica Lodziensia, 28.

Kostic B., Becht A., Aigner T., 2005, 3-D sedimentary architecture of a Quaternary gravel delta (SW-Germany): Implications for hydrostratigraphy, Sedimentary Geology, 181, s. 143-171. https://doi.org/10.1016/j.sedgeo.2005.07.004.

Kowalkowski A., 2004, Rozpoznawanie i klasyfikacja wytworzonych w środowisku peryglacjalnym i ekstraperyglacjalnym stref przekształceń i glebopokryw stokowych, Regionalny Monitoring Środowiska Przyrodniczego, 5, s. 47-94.

Lamparski P., 1992, Podpowierzchniowy system radarowy SIR-3, Przeglqad Geologiczny, 40, 11, s. $681-683$.

Lamparski P., 2001, Possibility of using Ground Penetrating Radar Method to determine the stratigraphy of the clastic deposits, [w:] Ground Penetrating Radar (GPR) in Sediments: Applications and Interpretation, 20-21.08.2001, Geological Society of London, University College London, Londyn, s. 34.

Lamparski P., 2004, Formy i osady czwartorzędowe w świetle badań georadarowych, Prace Geograficzne IGiPZ PAN, 194, Warszawa.

Lejzerowicz A., 2018, Internal architecture of fluvial deposits and the morphology of the selected sections of Narew River valley in Warsaw area (central Poland) based on GPR investigations, [W:] Proceedings of the $17^{\text {th }}$ International Conference on Ground Penetrating Radar (GPR), Rapperswil, 2018, s. 1-4. https://doi.org/10.1109/ICGPR.2018.8441570.

Lejzerowicz A., Czuryłowicz K., Kowalczyk S., Wysocka A., 2014, Ground Penetrating Radar and sedimentological investigations of quartz-glauconite sands in the Lubartów area (south-east Poland), [w:] Proceedings of the $15^{\text {th }}$ International Conference on Ground Penetrating Radar, GPR, 30.06-4.07.2014, Brussels, Belgium. https://doi.org/10.1109/ICGPR.2014.6970422.

Lejzerowicz A., Kowalczyk S., 2016, Fluvial architecture of Vistula River deposits in Nature Reserve Świderskie Islands (Warsaw area, central Poland) based on Ground Penetrating Radar (GPR) images, [W:] Proceedings of the $16^{\text {th }}$ International Conference on Ground Penetrating Radar (GPR), Hong Kong, 2016, s. 1-6. https://doi.org/10.1109/ICGPR.2016.7572597.

Lejzerowicz A., Kowalczyk S., 2018, Użyteczność badań GPR do identyfikacji cech wewnętrznych osadów rzeki Wisły na obszarach NATURA 2000, Prace i Studia Geograficzne, Wydział Geografii i Studiów Regionalnych Uniwersytetu Warszawskiego, 63, 2, s. 7-20.

Lejzerowicz A., Kowalczyk S., Wysocka A., 2012, Sedimentary architecture and ground penetrating radar (GPR) analysis of sandy-gravel esker deposits in Kozlow, Central Poland, [w:] Proceedings of the $14^{\text {th }}$ International Conference on Ground Penetrating Radar (GPR) June 4-8, 2012, Shanghai, China, s. 670-675. https://doi.org/10.1109/ICGPR.2012.6254946.

Lejzerowicz A., Kowalczyk S., Wysocka A., 2014, The usefulness of ground-penetrating radar images for the research of a large sand-bed braided river: case study from the Vistula River (central Poland), Geologos, 20, 1, s. 35-47. https://doi.org/10.2478/logos-2014-0003.

Lejzerowicz A., Wysocka A., Kowalczyk S., 2018, Application of Ground Penetrating Radar method combined with sedimentological analyses in studies of glaciogenic sediments in Central Poland, Studia Quaternaria, 35, 2, s. 103-119. https://doi.org/10.2478/squa-2018-0008.

Minet J.S., Lambot G., Delaide J.A., Huisman H., Vereecken H., Vanclooster M., 2010, A generalized frequency domain reflectometry modeling technique for soil electrical properties determination, Vadose Zone Journal, 9, s. 1063-1072. https://doi.org/10.2136/vzj2010.0004.

Moorman B.J., Judge A.S., Smith D.G., 1991, Examining fluvial sediments using ground penetrating radar in British Columbia, Geological Survey of Canada, Current Research, Part A, Paper 91-1A, s. 31-36. 
Morey R.M., 1974, Continuous subsurface profiling by impulse radar, [w:] Proceedings of Engineering Foundation Conference on Subsurface Exploration for Underground Excavation and Heavy Construction, New York, s. 213-232.

Neal A., 2004, Ground-penetrating radar and its use in sedimentology: principles, problems and progress, Earth-Science Reviews, 66, s. 261-330. https://doi.org/10.1016/j.earscirev.2004.01.004.

Niewiarowski W., 1959, Formy polodowcowe i typy deglacjacji na Wysoczyźnie Chełmińskiej, Studia Societatis Scientiarum Torunensis, sec. C, 6, 5, Toruń.

Niewiarowski W., 1961, Kemy okolic Leningradu i próba porównania ich z kemami polskimi, Przegląd Geograficzny, 33, s. 443-467.

Olszak J., Karczewski J., 2008, Przydatność profilowań georadarowych w interpretacji budowy tarasów rzecznych (dolina Kamienicy, polskie Karpaty Zewnętrzne), Przegląd Geologiczny, 56, 4, s. 330-334.

Overgaard T., Jakobsen P.R., 2001, Mapping of glaciotectonic deformation in an ice marginal environment with ground penetrating radar, Journal of Applied Geophysics, 47, 3-4, s. 191-197. https://doi.org/10.1016/S0926-9851 (01)00064-7.

Piotrowski A., 1989, Uwagi o paleogeografii jeziora Dabie w świetle badań radarowych prowadzonych w systemie SIR, Studia i Materiały Oceanologiczne, 56, Geologia Morza, 4, s. 289-291.

Raed A., Al-Asadi A., Mouazen M., 2014, Combining frequency domain reflectometry and visible and near infrared spectroscopy for assessment of soil bulk density, [w:] Soil and Tillage Research, 135, s. 60-70. https://dx.doi.org/10.1016/j.still.2013.09.002.

Razowski M., 1985, Opracowanie wyników badań radarowych przeprowadzonych w systemie SIR na jeziorze Dąbie i Roztoce Odrzańskiej w Szczecinie, Krakowskie Przedsiębiorstwo Geodezyjne.

Russel A.J., Knudsen Ó., Fay H., Marren P.M., Heinz J., Tronicke J., 2001, Morphology and sedimentology of a giant supraglacial, ice-walled, jökulhlaup channel, Skeiðarárjökull, Iceland: implications for esker genesis, Global and Planetary Change, 28, s. 193-216. https://doi.org/10.1016/ S0921-8181 (00)00073-4.

Sadura S., Martini I.P., Endres A.L., Wolf K., 2006, Morphology and GPR stratigraphy of a frontal part of an end moraine of the Laurentide Ice Sheet: Paris Moraine near Guelph, ON, Canada, Geomorphology, 75, s. 212-225. https://doi.org/10.1016/j.geomorph.2005.01.014.

Słowik M., 2011a, Changes of river bed pattern and traces of anthropogenic intervention: The example of using GPR method (the Obra River, western Poland), Applied Geography, 31, s. 784-799. https://doi.org/10.1016/j.apgeog.2010.08.004.

Słowik M., 2011b, Reconstructing migration phases of meandering channels by means of ground-penetrating radar (GPR): the case of the Obra River, Poland, Journal of Soils and Sediments, 11, 7, s. 1262-1278. https://doi.org/10.1007/s11368-011-0420-x.

Słowik M., 2012, Influence of measurement conditions on depth range and resolution of GPR images: The example of lowland valley alluvial fill (the Obra River, Poland), Journal of Applied Geophysics, 85, s. 1-14. https://doi.org/10.1016/j.jappgeo.2012.06.007.

Słowik M., 2014a, Reconstruction of anastomosing river course by means of geophysical and remote sensing surveys (the Middle Obra Valley, W Poland), Geografiska Annaler. Series A, Physical Geography, 96, s. 195-216. https://doi.org/10.1111/geoa.12042.

Słowik M., 2014b, Analysis of fluvial, lacustrine and anthropogenic landforms by means of ground penetrating radar (GPR): field experiment, Near Surface Geophysics, 12, s. 777-791. https://doi. org/10.3997/1873-0604.2014033.

Smith D.G., Jol H.M., 1995, Ground penetrating radar: antenna frequencies and maximum probable depths of penetration in Quaternary sediments, Journal of Applied Geophysics, 33, 1-3, s. 93-100. https://doi.org/10.1016/0926-9851 (95)90032-2. 
Terpiłowski S., 2008, Kemy jako wskaźnik deglacjacji Niziny Podlaskiej podczas zlodowacenia Warty, Lublin: Wydawnictwo Uniwersytetu Marii Curie-Skłodowskiej.

Theta Probe Soil Moisture Sensor Type ML2, User Manual, ML2-UM-1, 1998, Delta-T Devices Ltd., Burwell, Cambridge, England. https://www.delta-t.co.uk/wp-content/uploads/2016/11/ML2-Thetaprobe-UM.pdf (01.07.2020).

Topp G.C., Davis J.L., Annan A.P., 1980, Electromagnetic determination of soil water content: Measurements in coaxial transmission lines, Water Resoururces Research, 16, 3, s. 574-582. https:// doi.org/10.1029/WR016i003p00574.

Ulriksen C.P.F., 1982, Application of impulse radar to civil engineering, Lund.

Van Dam R.L., 2012, Landform characterization using geophysics - Recent advances, applications, and emerging tools, Geomorphology, 137, s. 57-73. https://doi.org/10.1016/j. geomorph.2010.09.005.

Van Dam R.L., Schlager W., 2000, Identifying the causes of ground-penetrating radar reflections using time-domain reflectometry and sedimentological analyses, Sedimentology, 47, s. 435-449. https://doi.org/10.1046/j.1365-3091.2000.00304.x.

Van Dam R.L., Van Den Berg E.H., Van Heteren S., Kasse C., Kenter J.A.M., Groen K., 2002, Influence of organic matter on radar-wave reflection: Sedimentological implications, Journal of Sedimentary Research, 72, s. 341-352. https://doi.org/10.1306/092401720341.

Van Loon A., Błaszkiewicz M., Degórski M., 2012, The role of permafrost in shaping the Late Glacial relief of northern Poland, Netherlands Journal of Geosciences, 91, 1-2, s. 223-231. https://doi. org/10.1017/S001677460000161X.

Van Overmeeren R.A., 1998, Radar facies of unconsolidated sediments in the Netherlands: a radar stratigraphy interpretation method for hydrogeology, Journal of Applied Geophysics, 40, 1-3, s. 1-18. https://doi.org/10.1016/S0926-9851 (97)00033-5.

Wysota W., 2007, Objaśnienia do Szczegółowej Mapy Geologicznej Polski w skali 1 : 50 000, ark. Golub-Dobrzyń (323), Centralne Archiwum Geologiczne PIG, Warszawa.

Żuk T., Sambrook Smith G.H., 2015, Stratygrafia radarowa - metoda analizy danych georadarowych 3D w badaniu środowisk sedymentacyjnych na przykładzie osadów rzecznych, Przegląd Geograficzny, 87, 3, s. 439-456.

\section{Summary}

The Ground Penetrating Radar (GPR) method potentially offers many possibilities for fast and reliable lithostratigraphic sediment models to be developed. From a cognitive point of view, this represents a major simplification and shortening of procedures with which information about sediments can be obtained. And from the point of view of the economy of operations, there can be a significant reduction in costs and time of research in shallow geology and the stratigraphy of areas where unconsolidated clastic sediments are of superficial occurrence. Also noteworthy is the possibility for the results of GPR surveys to be deployed in support of geological mapping, as well as in the shallow exploration of resources and hydrogeological studies.

The most major advantage of the GPR method related to the possibility of the structure of forms being observed in full shape. In the absence of large outcrops, geophysical prospection of geomorphological forms is helpful, insofar as we are able to translate the results of geophysical surveys into the actual lithostratigraphic system of sediments building a specific form. 
Against that background, the research presented in this article forms part of the work to develop radar stratigraphy, as an important support for direct geological research (Huggenberger et al., 1994; Van Overmeeren, 1998; Beres et al., 1999, Overgaard and Jakobsen, 2001; Jakobsen and Overgaard, 2002; Neal, 2004; Lejzerowicz et al., 2014; Żuk and Sambrook Smith, 2015; Lejzerowicz et al., 2018). It also points to the research potential of the GPR method in determining the genesis of form. The discussion on the way kames form (and even as regards the way they should be defined) has been going on in the literature for years (Niewiarowski, 1959; 1961; Karczewski, 1971; Klajnert, 1978; Jaksa, 2003; Terpiłowski, 2008). The studies presented here do not suffice to allow the matter to be determined comprehensively, even though they do provide for verification of the opinions of previous researchers. An example would be the observation of numerous faults in the whole mass of the western Owieczkowo kame (Fig. 7A), with this attesting to the creation of the form on ice, rather than on mineral ground (Niewiarowski, 1959).

The area forming the subject of this article is defined by Niewiarowski (1959) as the dead ice zone because of the characteristic set of forms (dead ice moraines, kames and eskers). Like modern researchers (Terpiłowski, 2008), Niewiarowski points to the importance of sub-Quaternary surface elevations in the formation of cracks in the ice sheet, with this leading on to the formation of kame hills above such elevations. This would also seem to have been one of the reasons for the formation in the mass of ice of lakes whose filling with sediment and melting ice walls took the form of kames.

The great advantage of the GPR method lies in its ability to recognise macrostructural sediment patterns in glacilimic forms. This diagnosis allows for the high-probability assessment of the genesis of form, especially in the context of its position being determined in the marginal zone of the ice sheet. Also looking extremely promising is the capacity for the thickness of fine clastic sediments lying on till to be determined using GPR. It allows for the determination of the way in which a given form is rooted.

Described as they are in brief only, test results for selected sites serve to confirm the great usefulness of the GPR method in the recognition of shallow lithostratigraphy of clastic sediments. Nevertheless, this should not be the only method used to recognise the geological structure of forms and sediments. Significant interpretation ambiguities mean that the GPR method should act in support of direct lithostratigraphic research, not merely serving as an alternative to it. GPR surveys offer a depiction particularly close to the real one - of sediment present in homogeneous sediments in relation to electrical parameters. Sediments ideal for GPR surveys would for example be fine dry sands or silts - and it is precisely these sediments that built most of the investigated kame forms.

Most of the field research presented in this article was financed as part of Ministry of Science and Higher Education Research Project No. N N306 281235 entitled "Genesis of selected glacial forms in the Polish Lowland in the light of geophysical georadar surveys". 